\title{
Gene Expression of Putative Pathogenicity-Related Genes in Verticillium dahliae in Response to Elicitation with Potato Extracts and during Infection Using Quantitative Real-Time PCR
}

\author{
Xiaohan Zhu, Arbia Arfaoui, Mohammad Sayari, Lorne R. Adam and Fouad Daayf *(D) \\ Department of Plant Science, University of Manitoba, 222 Agriculture Building, Winnipeg, MB R3T2N2, Canada; \\ huhu772@hotmail.com (X.Z.); arbia_arfaoui2002@yahoo.fr (A.A.); Mohammad.Sayari@umanitoba.ca (M.S.); \\ Lorne.Adam@umr.umanitoba.ca (L.R.A.) \\ * Correspondence: Fouad.Daayf@umanitoba.ca
}

check for updates

Citation: Zhu, X.; Arfaoui, A.; Sayari, M.; Adam, L.R.; Daayf, F. Gene Expression of Putative

Pathogenicity-Related Genes in Verticillium dahliae in Response to Elicitation with Potato Extracts and during Infection Using Quantitative Real-Time PCR. Pathogens 2021, 10, 510. https://doi.org/10.3390/ pathogens 10050510

Academic Editor: Lawrence S. Young

Received: 18 March 2021

Accepted: 21 April 2021

Published: 23 April 2021

Publisher's Note: MDPI stays neutral with regard to jurisdictional claims in published maps and institutional affiliations.

Copyright: (C) 2021 by the authors. Licensee MDPI, Basel, Switzerland. This article is an open access article distributed under the terms and conditions of the Creative Commons Attribution (CC BY) license (https:// creativecommons.org/licenses/by/ $4.0 /)$.

\begin{abstract}
Quantitative real-time PCR was used to monitor the expression of 15 Verticillium dahliae's genes, putatively involved in pathogenicity, highly (HAV) and weakly aggressive (WAV) V. dahliae isolates after either (i) elicitation with potato leaf, stem, or root extracts, or (ii) inoculation of potato detached petioles. These genes, i.e., coding for Ras-GAP-like protein, serine/threonine protein kinase, Ubiquitin-conjugating enzyme variant-MMS2, NADH-ubiquinone oxidoreductase, Thioredoxin, Pyruvate dehydrogenase E1 VdPDHB, myo-inositol 2-dehydrogenase, and HAD-superfamily hydrolase, showed differential upregulation in the HAV versus WAV isolate in response to plant extracts or after inoculation of potato leaf petioles. This suggests their potential involvement in the observed differential aggressiveness between isolates. However, other genes like glucan endo-1,3alpha-glucosidase and nuc-1 negative regulatory protein VdPREG showed higher activity in the WAV than in the HAV in response to potato extracts and/or during infection. This, in contrast, may suggest a role in their lower aggressiveness. These findings, along with future functional analysis of selected genes, will contribute to improving our understanding of $V$. dahliae's pathogenesis. For example, expression of $V d P R E G$ negatively regulates phosphorus-acquisition enzymes, which may indicate a lower phosphorus acquisition activity in the WAV. Therefore, integrating the knowledge about the activity of both genes enhancing pathogenicity and those restraining it will provide a guild line for further functional characterization of the most critical genes, thus driving new ideas towards better Verticillium wilt management.
\end{abstract}

Keywords: Verticillium dahliae; effectors; defense inducers; highly aggressive; gene expression

\section{Introduction}

Verticillium wilt, caused by $V$. dahliae or V. albo-atrum, is a major disease that engenders significant yield losses in potato production, valued at millions of dollars each year [1]. Additionally, referred to as potato early dying (PED), this disease can cause 5 to 12 metric tons of tuber yield loss per hectare, and result in up to $90 \%$ disease severity [1-4]. Previous research showed a correlation between the density of $V$. albo-atrum in the soil and severity of wilt symptoms under favorable conditions [5]. V. dahliae has a larger host range than $V$. albo-atrum [1], affecting more than 200 dicotyledonous plant species including flowers, oilseed and fiber crops, fruits, vegetables, and woody perennials $[1,4]$.

$V$. dahliae produces microsclerotia that can be released in the soil and remain viable for 10 to 15 years $[4,6]$. Microsclerotia germinate in response to stimulation by root exudates secreted in the rhizosphere [7] and later reach the plant roots [8]. V. dahliae can enter the susceptible plants from the root tip, then extend to cross the endodermis and penetrate the young xylem elements, finally reaching the vascular cylinder [9]. $V$. dahliae sporulates in the vascular tissue and moves following the sap stream, but may be trapped in pit cavities [8]. 
Their conidia germinate in the vessel end walls and penetrate the adjacent elements for future propagation in the host [8].

Plants have evolved a series of defense mechanisms against $V$. dahliae [10]. Some plant species such as tomato, pea, and cotton, can compromise the expansion of $V$. dahliae by increasing the production of lignin-like phenolic polymers or lignin depositions in cortical plant cell walls $[11,12]$. In tomato, $V e$-mediated plant resistance to $V$. dahliae involves the accumulation of lignin [13], which can decrease microsclerotia's viability even in crop residues in the soil [14]. Additionally, plants accumulate several enzymes, including peroxidase, phenylalanine ammonia-lyase (PAL), and cinnamyl alcohol dehydrogenase, which are involved in plant resistance to $V$. dahliae [11,13]. Similarly, cotton plant cells reinforce their walls by the accumulation of polysaccharides (callose and cellulose) and release phytoalexins (i.e., coumarins, terpenoids) in response to infection by $V$. dahliae [15-17]. When $V$. dahliae enters the xylem vessels, plant vascular cell walls may produce coating materials such as cellulose to prevent fungal horizontal spread. In addition, the neighboring parenchyma cells produce paramural deposition such as pectin, callose, and cellulose [18].

Commonly used strategies to manage Verticillium wilt in crops include cultural practices such as crop rotations, and sometimes the use of fumigants [19]. However, none of these methods provide full control of the disease. Crop rotation of up to 5 years does not suppress the disease effectively [20] due to the long-lasting survival of microsclerotia in soil and the wide host range of $V$. dahliae $[1,6]$. Furthermore, once $V$. dahliae enters the plant vascular tissues, no fungicide were shown to control it [8].

Understanding the molecular mechanism that make $V$. dahliae a strong pathogen, including the identification of genes that are critical for infection [21], would set the ground for the development of better alternative approaches to control the wilt disease it causes. A previous proteomics study showed differential accumulation of a set of proteins in highly aggressive versus weakly aggressive isolates of $V$. dahliae [22]. Another study demonstrated differential gene expression in a highly versus weakly aggressive isolates in response to potato root extracts [23]. One of these genes, an isochorismatase hydrolase, was later found to be involved in $V$. dahliae's interference with potato's SA defense pathway [24]. The differentially expressed proteins Thioredoxin (VdTRX) (VDAG_04529), NADH-ubiquinone oxidoreductase (VDAG_09026), Pyruvate dehydrogenase E1 component subunit beta (VdPDHB) (VDAG_01642), Ubiquitin-conjugating enzyme variant MMS2 (VDAG_05365), HAD-superfamily hydrolase (VDAG_08490), Serine 3-dehydrogenase (VDAG_09532), and Wos2 (VDAG_08865), were visible only in the highly aggressive isolate's profile [22]. Genes encoding Ras-GAP like protein (VDAG_01012), Xanthine dehydrogenase (VDAG_07735), myo-inositol 2-dehydrogenase (VDAG_08205), and DNA(apurinic or apyrimidinic site) lyase (DNA AP lyase) (VDAG_02445), were also upregulated in the highly aggressive isolate in response to root extracts from both susceptible and moderately resistant potato cultivars [23]. Genes such as those coding for serine/threonine protein kinase (VDAG_04632), glucan endo-1,3-alpha-glucosidase agn1 (VDAG_04101), DNA repair protein RAD51 (VDAG_08796), and nuc-1 negative regulatory protein preg (PREG) (VDAG_06766) were upregulated in both highly and weakly aggressive isolates in response to potato root extracts [23]. The two transcriptomic and proteomic studies by El-Bebany et al. [22,23] clearly showed the differential ability of highly versus weakly aggressive isolates to express genes and/or proteins both constitutively in vitro, or as a response to potato root extracts. We chose 15 most prominent of those genes and proteins for further investigation in the current study, as they previously showed involvement in host-pathogen interaction. For example, Agn1 codes for an important enzyme during cytokinesis in fission-yeast. It is delivered to the interface between the cell wall and out layer of primary septum, and then participates in cell separation [25-29]. A ubiquitin binding site of Yeast Ubiquitin E2 Variant (UEV) Protein MMS2 is essential for DNA-damage tolerance controlled by the RAD6 pathway [30]. Serine 3-dehydrogenase is involved in the catabolism of serine. A serine 3-dehydrogenase in mammalian fungi pathogen Paracoccidioides lutzii interacts with host macrophages and may play roles in colonization and spread 
into the host [31,32]. Myo-inositol dehydrogenase is essential for inositol and inositol phosphate metabolism in aerobacter, the ability of nitrogen fixation and nodulation for host in Sinorhizobium fredii, and rhizopine utilization in S. meliloti [33-35]. Ras-GAP protein and serine threonine protein kinase are involved in close-related signaling transduction, controlling cell differentiation and proliferation. Ras protein regulates signaling transduction in cell growth and differentiation in both mammals and fungi. Ras-GAP protein inactivates Ras protein by accelerating the conversion from GTP-bound Ras active state to GDP-bound inactive state [36,37]. Serine/threonine protein kinases play important roles in signal transduction for fungal development and proliferation as well as in morphogenesis changes during infection [38]. The Ras family proteins can be activated by serine/threonine protein kinase [39]. Moreover, Ras protein can also control serine/threonine protein kinase to regulate the pathogenicity in various fungi [40-42]. Wos2 is important for cell proliferation in the yeast $S$. pombe [43]. Pyruvate dehydrogenase E1 component subunit beta is required for full assembly of the Pyruvate dehydrogenase multienzyme complex (PDHc), while full functionality of this complex is critical in catalyzing pyruvate into acetyl-CoA [44-47]. Xanthine dehydrogenase catalyzes xanthine to uric acid and also participated in purines and pyrimidines oxidation in various organisms including chicken and Arabidopsis thaliana [48-52].

As the next step, the objective of this study was to assess the expression pattern of these most prominent 15 genes, clustered in different groups according to their functions (i) in response to elicitation with different potato extracts, and (ii) during infection of the petiole of detached potato leaves by each of two $V$. dahliae isolates with contrasting levels of aggressiveness. For this purpose, and to mimic as much as possible what happens in nature, we first assessed the gene expression in $V$. dahliae in response to potato plant exudates; then, we investigated their expression during infection of potato detached leaves. Thus far, no studies have assessed the expression of these genes with respect to understanding their potential involvement in pathogenicity of $V$. dahliae. In addition, this study provides an integrated overview of how the most prominent genes express during two important phases of their lifecycles: induction by plant exudates and actual tissue infection.

\section{Results}

\subsection{Isolate Aggressiveness and Disease Assessment}

The highly aggressive isolate (Vd1396-9) induced significantly more disease measured as total AUDPC of "percentage of infection" and "disease severity" than the weakly aggressive isolate (Vs06-07) or water control (Figure 1A,B). The plant growth rate of potato inoculated with Vd1396-9 was significantly lower than that of the other two treatments (Figure 1C). Potato plants inoculated with Vd1396-9 exhibited more symptoms at 5 weeks after inoculation (WAI) than plants inoculated with Vs06-07 or water (Figure 1D). The percentage of infection of plants inoculated with the weakly aggressive isolate was only slightly higher than in the water control, but significantly lower than with the highly aggressive one (Figure 2A). The plants inoculated with the weakly aggressive isolate showed similar disease severity and plant growth rates as water controls (Figure 2B-D). 

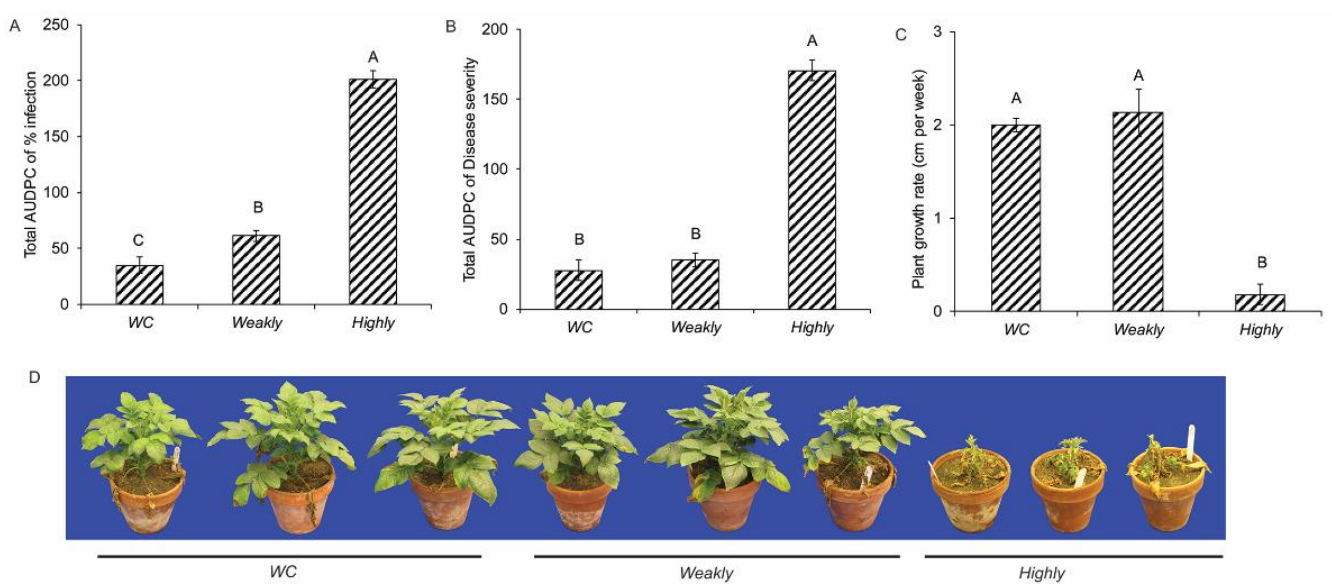

Figure 1. Pathogenicity analysis of the highly (Vd1396-9) and weakly aggressive (Vs06-07) V. dahliae isolates on the susceptible potato cultivar Kennebec. (A) Total AUDPC of percent infection; (B) total AUDPC of disease severity; (C) growth rate of potato plants per week (cm); (D) potato plants infected with WC, Weakly and Highly aggressive isolates at 5 weeks after inoculation. WC: Water control treatment; Weakly: weakly aggressive $V$. dahliae isolate Vs06-07; Highly: highly aggressive V. dahliae isolate Vd1396-9. Error bars refer to standard errors. The macro PDMIX800.sas [53], $\alpha=0.05$ was applied to mean values separated by least squared means, and into grouped letters' results. Values $(n=3)$ with the same letters are not significantly different $(p<0.05)$.

\subsection{Differential Fungal Gene Expression in Response to Elicitation with Potato Extracts and Inoculation}

All of the 15 genes/proteins used in this research were processed for prediction for fungal signal peptides and effectors by machine-learning with SignalP 5.0 (http:/ / www.cbs. dtu.dk/services/SignalP / (accessed on 7 March 2021)) [54] and EffectorP (http: / / effectorp. csiro.au/ (accessed on 7 March 2021)) [55,56]. Glucan endo-1,3-alpha-glucosidase agn1 was predicted as a secretory protein with a probability of 0.9129 (Supplementary Table S1 and Figure S1). Ubiquitin-conjugating enzyme variant MMS2, Serine 3-dehydrogenase, and myo-inositol 2-dehydrogenase were predicted as fungal effectors (Table S2).

Most of the selected investigated genes in the current study showed higher expression in the highly aggressive isolate during infection of the detached leaves. However, the same genes exhibited different expression patterns depending on elicitation of potato root, stem, or leaf extracts. In this study, gene expression with fold change $\geq 2$ were defined as up-regulated, and fold change $\leq 0.5$ were defined as down-regulated.

\subsubsection{Genes Involved in Cell Differentiation and Proliferation}

Four genes involved in cell differentiation and proliferation were assessed: Ras protein, serine/threonine protein kinase, Wos2, and glucan endo-1,3-alpha-glucosidase. Most of these genes were upregulated (fold change $\geq 2$ ) in both highly and weakly aggressive isolates of $V$. dahliae in response to elicitation with different potato extracts (Figure 2A,C,E,G). The expression of both Ras-GAP and serine/threonine protein kinase was more noticeable in the highly than the weakly aggressive isolate in response to the stem extracts (Figure 2A,C).

During infection of detached potato leaves, both tested isolates had increases in transcripts of Ras-GAP, serine/threonine protein kinase, and endo-1,3-alpha-glucosidase (Figure 2B,D,F). 

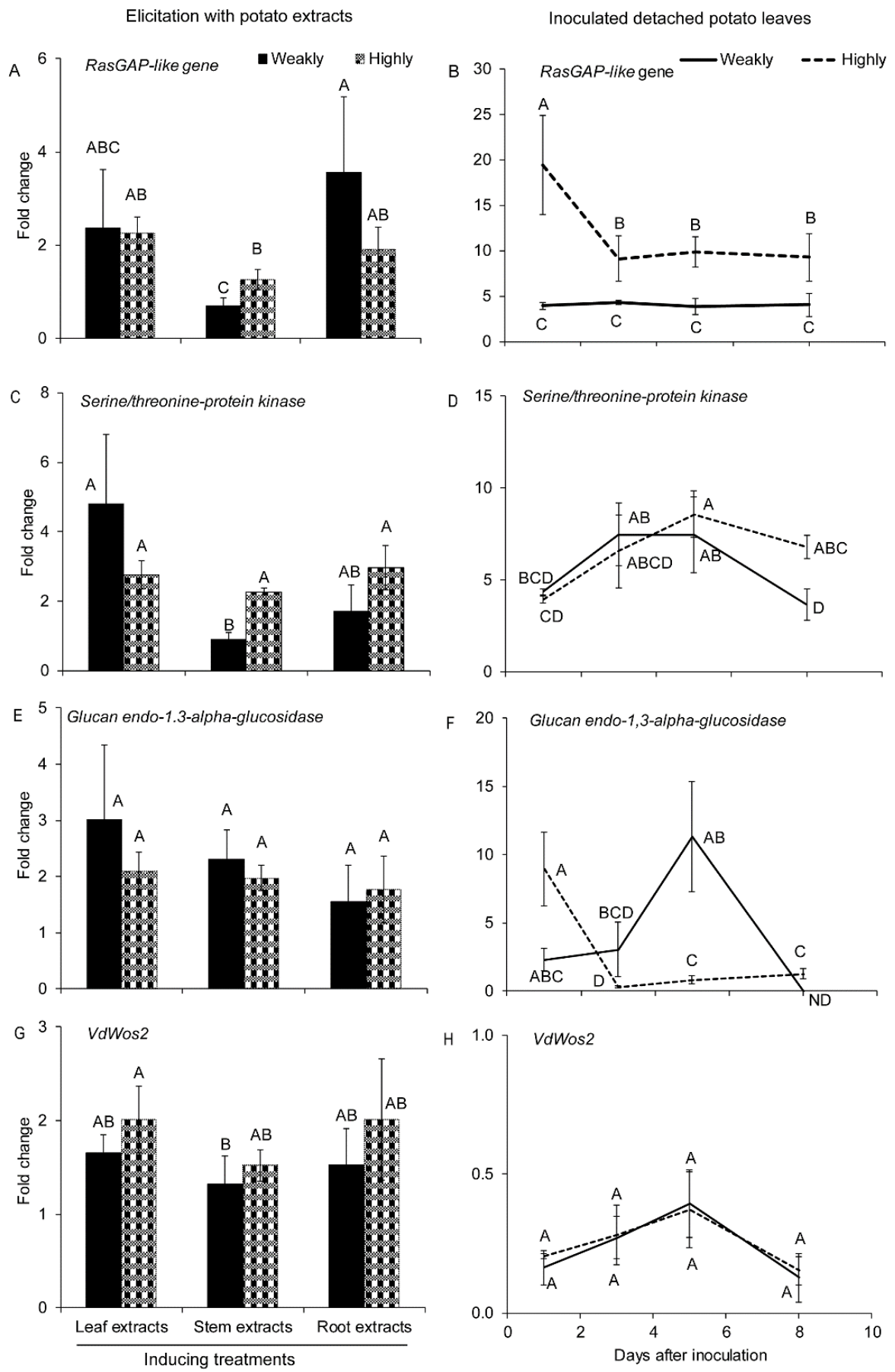

Figure 2. Expression of genes involved in cell differential and proliferation under different treatments. Expression of (A) Ras-GAP like protein, (C) serine/threonine protein kinases, (E) glucan endo-1,3alpha-glucosidase and (G) VdWos2 in the highly (Vd1396-9) and the weakly (Vs06-07) aggressive $V$. dahliae isolates in response to elicitation with different potato extracts: leaf, stem, root extracts. Expression of (B) Ras-GAP like protein, (D) serine/threonine protein kinases, (F) glucan endo-1,3alpha-glucosidase and (H) VdWos2 in the highly (Vd1396-9) and the weakly (Vs06-07) aggressive $V$. dahliae isolates in response to infection of detached potato leaves at 1,3,5, and 8 DAI. WC: Water control treatment; Weakly: weakly aggressive V. dahliae isolate Vs06-07; Highly: highly aggressive $V$. dahliae isolate Vd1396-9; ND: Non-detectable. Error bars refer to standard error. The macro PDMIX800.sas [53], $\alpha=0.05$ was applied to mean values separated by least squared means, and into grouped letters' results. Values $(n=3)$ with the same letters are not significantly different $(p<0.05)$. 
The accumulation of Ras-GAP transcripts was significantly higher in the highly aggressive isolate than the weakly aggressive one (Figure 2B). This was evident throughout the entire monitored period, but especially so at the early stages of infection (Figure 2B). Serine/threonine protein kinase gene reached a maximum expression in the highly aggressive isolate from 5 to 8 DAI, which was also significantly higher than the weakly aggressive one at 8 DAI (Figure 2D). The expression of endo-1, 3-alpha-glucosidase in the weakly aggressive isolate peaked at 5DAI and was higher than in the highly aggressive isolate during infection of detached leaves. In the same experiment, the expression of Wos2 was downregulated in both isolates (fold change $\leq 0.5$ ) (Figure 2F,H).

\subsubsection{Genes Involved in DNA Repair}

We assessed the expression of three genes involved in DNA damage repair of postreplicative processes. DNA-(apurinic or apyrimidinic site) lyase, ubiquitin-conjugating enzyme variant MMS2, and DNA repair protein RAD51 had been well investigated in yeast and mammals [57-61].

In most cases in our study, these three genes were up regulated in one or both isolates in response to potato extracts (Figure 3A,C,E). The expression of DNA-(apurinic or apyrimidinic site) lyase and RAD51 coding genes were higher in the weakly aggressive isolate following exposure to the potato root extract (Figure 3A,E). RAD51-coding gene, also exhibited the same response to leaf extract (Figure 3E). We also noted increased expression of RAD51-coding gene in the pre-infection stage in the weakly aggressive isolate (Figure $3 \mathrm{E}$ ). During infection of detached leaves, only the DNA-(apurinic or apyrimidinic site) lyase-coding gene showed an increase (fold change $\geq 2$ ) in both $V$. dahliae isolates (Figure 3B). The expression of this gene also increased with root extract elicitation, suggesting its involvement in both pre-infection and infection stages. The expression of the MMS2-coding gene in the weakly aggressive isolate during infection was suppressed (fold change $\leq 0.5$ ) and significantly lower than in the highly aggressive isolate (Figure 3D). The expression of RAD51-coding gene was opposite to MMS2, in that its expression in the highly aggressive isolate was lower than in the weakly one at 1 and 8 DAI (Figure 3F).

\subsubsection{Genes Related to ROS Production and Cleavage}

Two genes related to ROS balance, thioredoxin (Trx) and NADPH ubiquinone oxidoreductasecoding genes, were assessed. Both isolates increased their expression of Trx in response to potato root extract elicitation and during detached leaf infection (Figure 4A,B). However, during detached leaves' infection, in the highly aggressive isolate, Trx reached a dramatically high level of expression at 5 DAI and then fell back down at 8 DAI (Figure 4B). Overall, Trx expression was still higher than in the weakly aggressive isolate (Figure 4B). The expression of NADH-ubiquinone oxidoreductase-coding gene increased in the highly aggressive isolate in response to all three forms of potato extracts, though only the stem extract was statistically significant (Figure 4C). During detached leaf infection, its expression in the highly aggressive isolate was only slightly increased at $8 \mathrm{DAI}$, whereas its expression in the weakly aggressive isolate was significantly lower than in the highly aggressive isolate from 5 DAI (Figure 4D). 
Elicitation with potato extracts
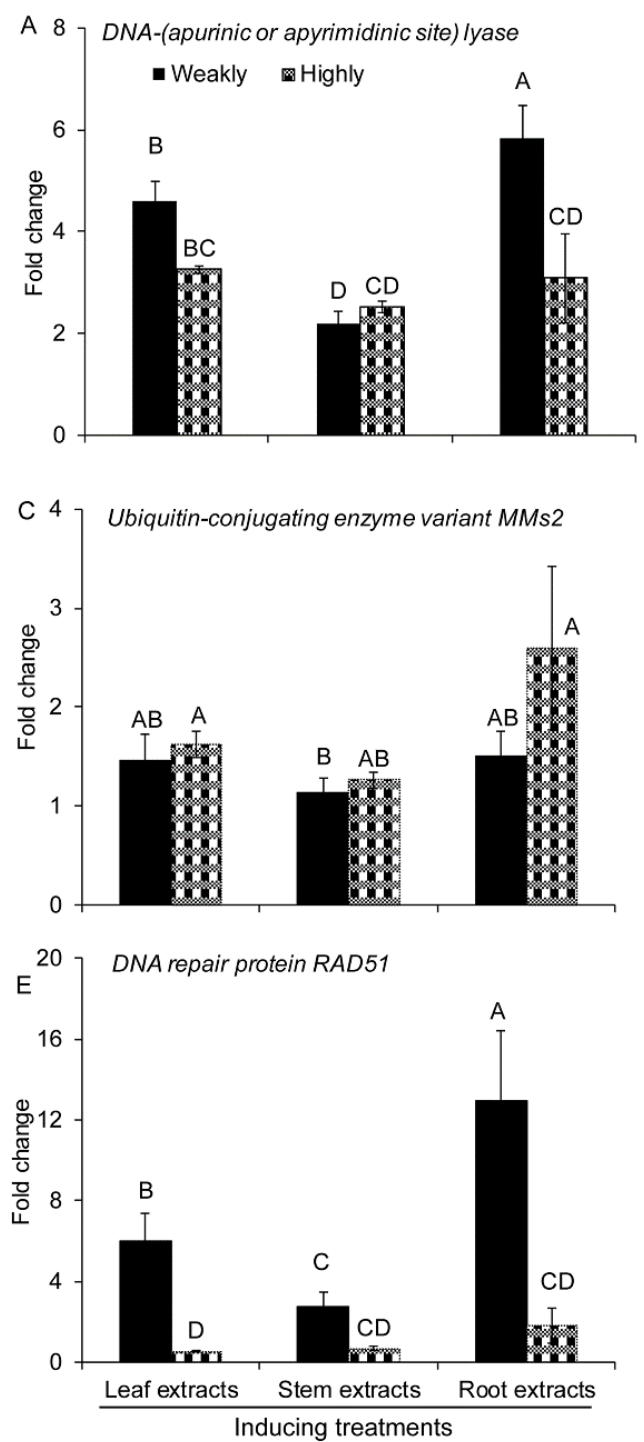

Inoculated detached potato leaves
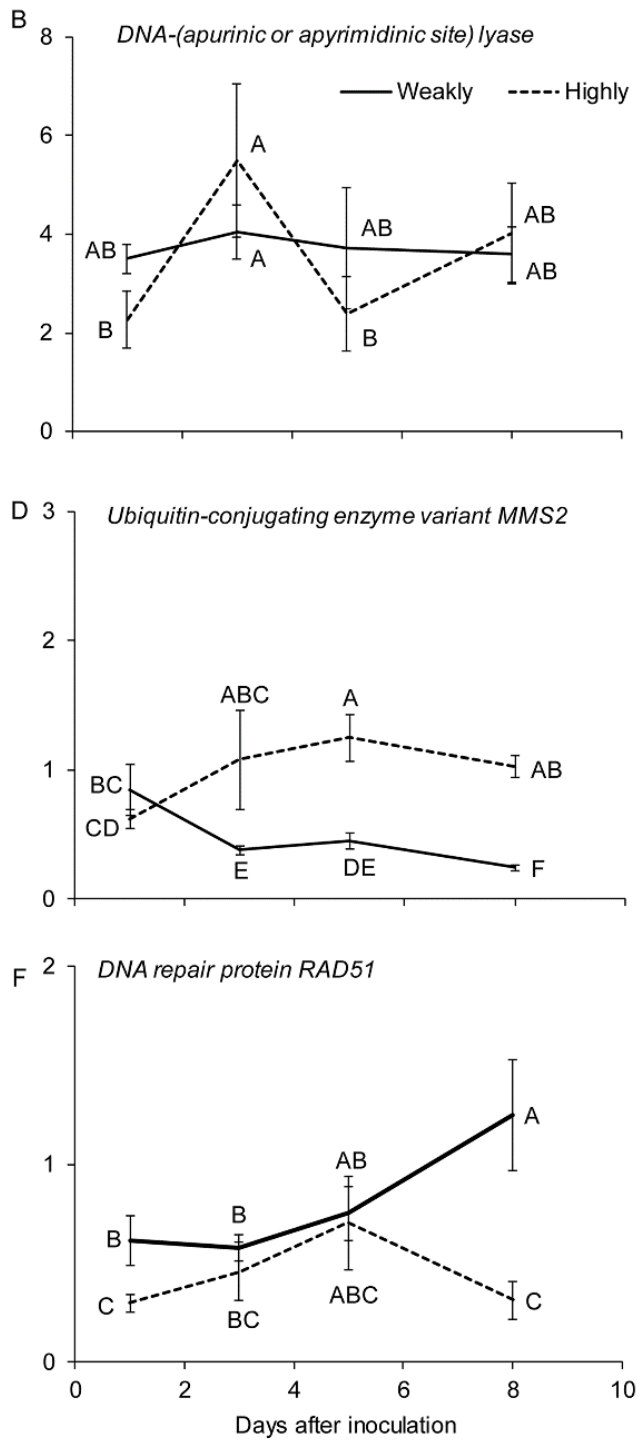

Figure 3. Expression of genes involved in DNA repair under different treatments. Expression of (A) DNA-(apurinic or apyrimidinic site) lyase, (C) ubiquitin-conjugating enzyme variant MMS2, and (E) DNA repair protein RAD51 in the highly (Vd1396-9) and the weakly (Vs06-07) aggressive V. dahliae isolates in response to elicitation with different potato extracts: leaf, stem, root extracts. Expression of (B) DNA-(apurinic or apyrimidinic site) lyase, (D) ubiquitin-conjugating enzyme variant MMS2, and (F) DNA repair protein RAD51 in the highly (Vd1396-9) and the weakly (Vs06-07) aggressive $V$. dahliae isolates in response to infection of detached potato leaves at 1, 3, 5, and 8 DAI. WC: Water control treatment; Weakly: weakly aggressive $V$. dahliae isolate Vs06-07; Highly: highly aggressive $V$. dahliae isolate Vd1396-9. Error bars refer to standard error. The macro PDMIX800.sas [53], $\alpha=$ 0.05 was applied to mean values separated by least squared means, and into grouped letters results. Values $(n=3)$ with the same letters are not significantly different $(p<0.05)$. 
Elicitation with potato extracts
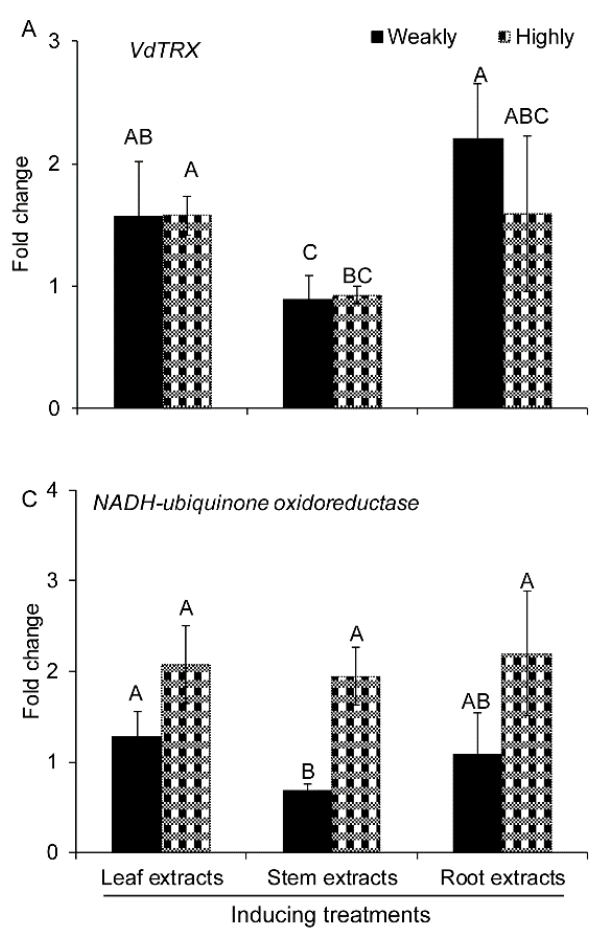

Inoculated detached potato leaves
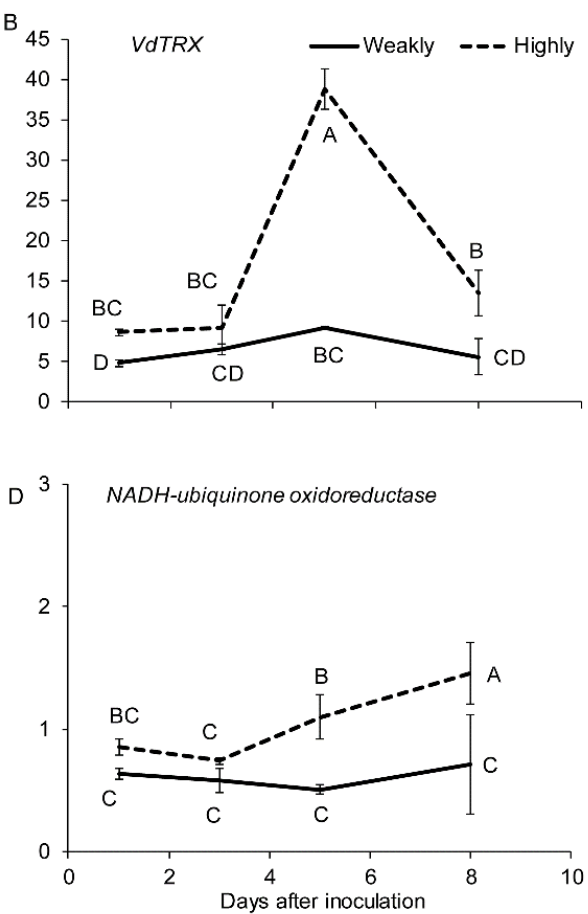

Figure 4. Expression of genes involved in ROS regulation under different treatments. Expression of (A) Thioredoxin (Trx) and (C) NADH-ubiquinone oxidoreductase in the highly (Vd1396-9) and the weakly (Vs06-07) aggressive $V$. dahliae isolates in response to elicitation with different potato extracts: leaf, stem, root extracts. Expression of (B) Trx and (D) NADH-ubiquinone oxidoreductase in the highly (Vd1396-9) and the weakly (Vs06-07) aggressive $V$. dahliae isolates in response to infection of detached potato leaves at 1,3,5, and 8 DAI. WC: Water control treatment; Weakly: weakly aggressive $V$. dahliae isolate Vs06-07; Highly: highly aggressive V. dahliae isolate Vd1396-9. Error bars refer to standard error. The macro PDMIX800.sas [53], $\alpha=0.05$ was applied to mean values separated by least squared means, and into grouped letters results. Values $(n=3)$ with the same letters are not significantly different $(p<0.05)$.

\subsubsection{Genes Related to Cellular Metabolism}

Cellular metabolism includes many chemical reactions involved in maintaining normal life for an organism. The expression of Serine 3-dehydrogenase, pyruvate dehydrogenase E1 component subunit beta, xanthine dehydrogenase, myo-inositol dehydrogenase, and nuc-1 negative regulatory protein VdPREG coding genes, all involved in cell metabolism, were assessed. These genes are involved in catabolism of serine, conversion of pyruvate to Acetyl-CoA, oxidative metabolism of purines and pyrimidines, inositol, and inositol phosphate metabolism, and the regulation of the activity of transcription factor NUC-1, respectively [31,35,44,46,48,51,62,63].

In general, the expression of Serine 3-dehydrogenase, pyruvate dehydrogenase E1 component subunit beta and xanthine dehydrogenase increased in both $V$. dahliae isolates in response to potato extracts (Figure 5A,C,E). During infection, the expression of Serine 3-dehydrogenase and xanthine dehydrogenase was significantly up-regulated over time in the highly aggressive $V$. dahliae isolate. However, the expression of these two genes in the weakly aggressive isolate either decreased or did not change (Figure 5B,F). In addition, the highly aggressive isolate exhibited more transcripts of serine 3-dehydrogenase in response to root extracts (Figure 5A). This was also true for the highly aggressive isolate's expression during infection of detached leaves (Figure 5B). Serine 3-dehydrogenase, pyruvate dehydrogenase E1 component subunit beta, and xanthine dehydrogenase all exhibited higher activities in the highly than the weakly aggressive $V$. dahliae isolate (Figure 5A-F). 
Elicitation with potato extracts
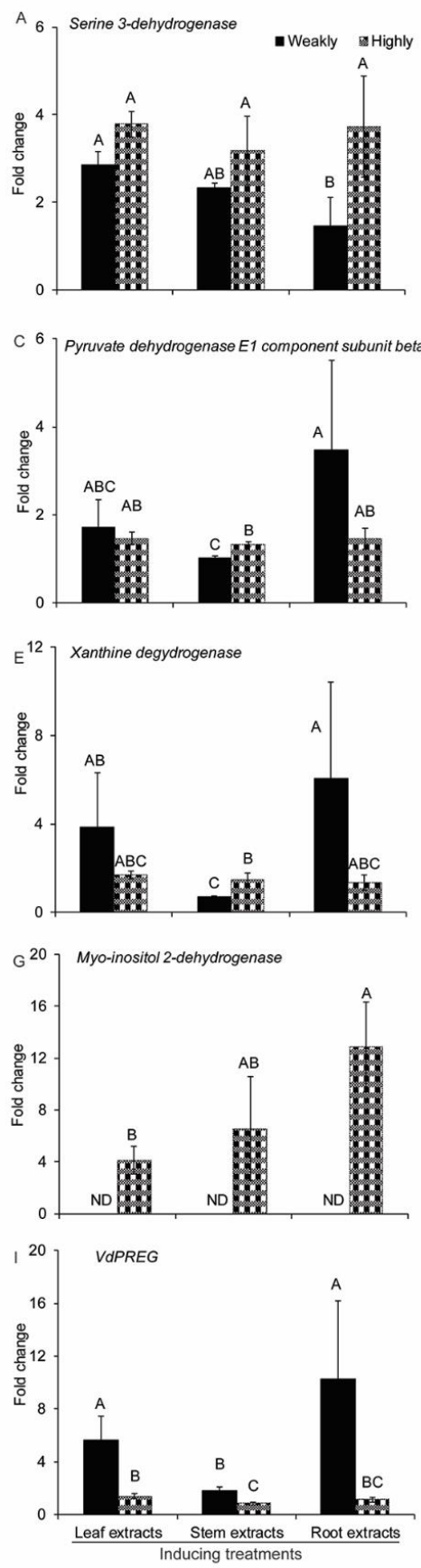

Inoculated detached potato leaves

B

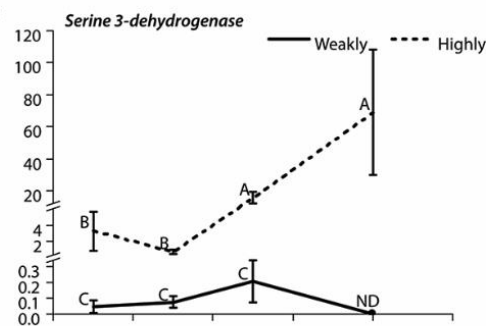

D 3 Pyruvate dehydrogenase E1 component subunit beta

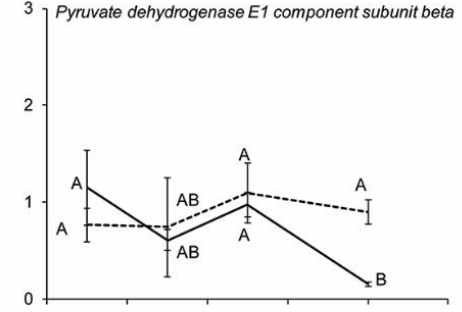

$\left.\mathrm{F}^{5}\right]$ Xanthine dehydrogenase gene
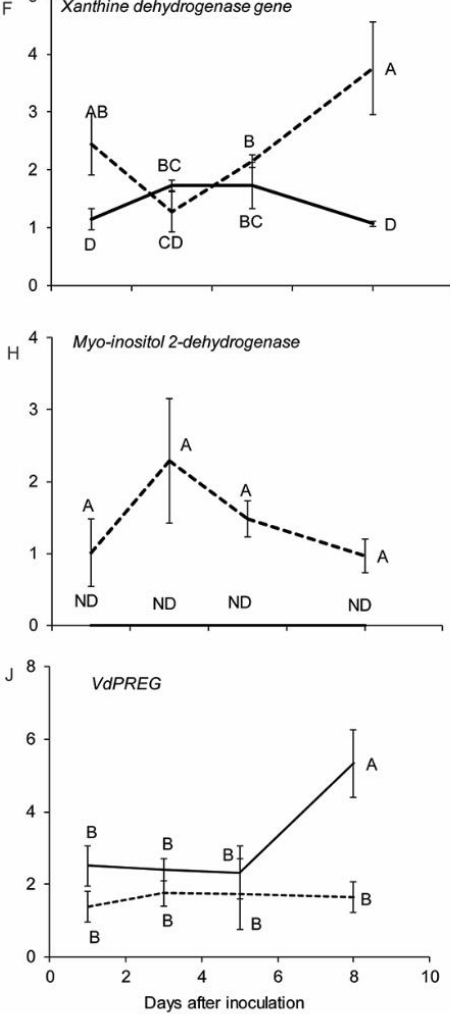

Figure 5. Expression of genes related to cellular metabolism under different treatments. Expression of (A) Serine 3-dehydrogenase, (C) Pyruvate dehydrogenase E1 component subunit beta, (E) Xanthine dehydrogenase, (G) Myo-inositol dehydrogenase, and (I) VdPREG in the highly (Vd1396-9) and the weakly (Vs06-07) aggressive $V$. dahliae isolates in response to elicitation with different potato extracts: leaf, stem, root extracts. Expression of (B) Serine 3-dehydrogenase, (D) Pyruvate dehydrogenase E1 component subunit beta, (F) Xanthine dehydrogenase, (H) Myo-inositol dehydrogenase, and (J) VdPREG in the highly (Vd1396-9) and the weakly (Vs06-07) aggressive V. dahliae isolates in response to infection of detached potato leaves at 1,3,5, and 8 DAI. WC: Water control treatment; Weakly: weakly aggressive $V$. dahliae isolate Vs06-07; Highly: highly aggressive V. dahliae isolate Vd1396-9; ND: Non-detectable. Error bars refer to standard error. The macro PDMIX800.sas [53], $\alpha=0.05$ was applied to mean values separated by least squared means, and into grouped letters' results. Values $(\mathrm{n}=3)$ with the same letters are not significantly different $(p<0.05)$. 
The expression level of myo-inositol dehydrogenase-coding gene in the highly aggressive isolate was up-regulated in response to potato extracts and during infection of detached leaves, but we were unable to detect its expression in the weakly aggressive isolate in any of the treatments (Figure $5 \mathrm{G}, \mathrm{H}$ ). The expression of nuc- 1 negative regulatory protein VdPREG in the weakly aggressive $V$. dahliae isolate was significantly higher than in the highly aggressive one under all treatments, as well as during infection at 8 DAI (Figure 5I,J).

\subsubsection{Genes Related to Detoxification}

HAD superfamily hydrolase constitutes the largest branch of phosphatases superfamily [64,65]. In Escherichia coli and S. cerevisiae, several homologues of HAD-like hydrolase coding gene were identified [66,67]. These homologues have a role in the detoxification of 2-deoxyglucose or phosphorylated glycerol phosphates and carbohydrates $[66,67]$.

The expression of HAD in $V$. dahliae was not significantly different between the two isolates in response to potato extracts (Figure 6A). However, during the detached leaves' infection, HAD superfamily hydrolase transcripts accumulated more in the highly aggressive isolate (Figure 6B). Following infection, there was an increasing versus decreasing expression trends in the highly versus weakly aggressive isolates, respectively (Figure 6B).

Elicitation with potato extracts

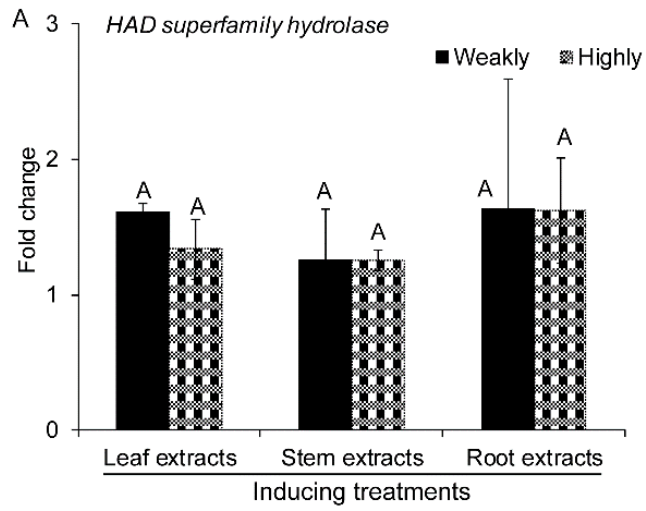

Inoculated detached potato leaves

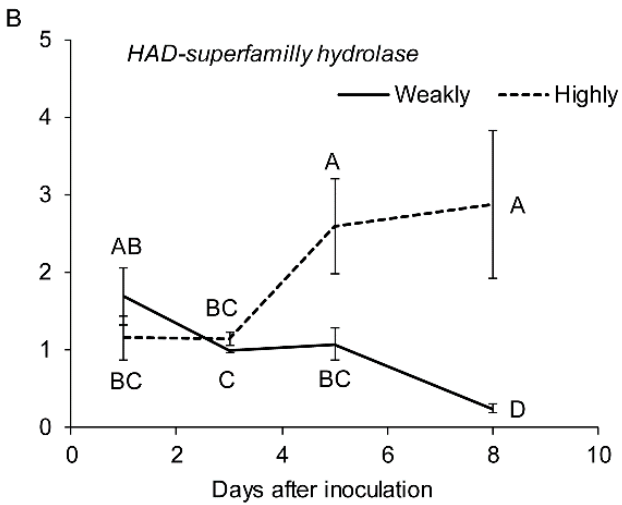

Figure 6. Expression of genes related to detoxification under different treatments. (A) Expression of HAD superfamily hydrolase in the highly (Vd1396-9) and the weakly (Vs06-07) aggressive V. dahliae isolates in response to elicitation with different potato extracts: leaf, stem, root extracts. (B) Expression of HAD superfamily hydrolase in the highly (Vd1396-9) and the weakly (Vs06-07) aggressive $V$. dahliae isolates in response to infection of detached potato leaves at $1,3,5$, and 8 DAI. WC: Water control treatment; Weakly: weakly aggressive V. dahliae isolate Vs06-07; Highly: highly aggressive $V$. dahliae isolate Vd1396-9. Error bars refer to standard error. The macro PDMIX800.sas [53], $\alpha=$ 0.05 was applied to mean values separated by least squared means, and into grouped letters results. Values $(n=3)$ with the same letters are not significantly different $(p<0.05)$.

\section{Discussion}

$V$. dahliae causes one of the most devastating potato diseases, leading to great losses worldwide [1]. Comprehending the molecular mechanisms of infection, colonization, and tissue damage are important tools towards the development of sustainable management of this disease in the field [1,4]. This study provides more comparative details about the quantitative expression of 15 genes involved in different cellular processes in two $V$. dahliae isolates possessing differential levels of aggressiveness (highly aggressive Vd1396-9 versus weakly aggressive Vs06-07). The 15 genes included in the current study showed differential expression when comparing a highly and a weakly aggressive isolates, and in response to potato root extracts [23]. In order to provide as complete a picture as possible, we assessed the expression of these $15 \mathrm{~V}$. dahliae genes in two different settings that would relate to two different phases of $V$. dahliae's interaction with potato in nature. Firstly, our assessment of 
gene expression in $V$. dahliae in response to plant exudates mimics the pre-infection phase when the pathogen senses the presence of the host roots. Secondly, assessment of gene expression in detached petiole/leaves mimics a phase in the host infection process.

Ras-GAP-like protein, serine/threonine protein kinase, Wos2, and glucan endo-1,3alpha-glucosidase are involved in regulating cell differentiation and proliferation. The increased activity of the above mentioned genes during exposure to potato extracts, or during infection process, shows that these genes may be involved in spore germination and other cellular processes leading to infection by $V$. dahliae. This result is in line with previous findings in Candida albicans (behaves as a pathogenic yeast in human under specific conditions), which showed transient increases in Rho1-GAP (Rho1 belongs to Ras family) and WOS2 during a morphogenesis switch from a less-virulent yeast to a more-virulent filamentous form [68]. Ras-GAP's involvement parallels findings that RasGAP is important for cell differentiation, such as yeast in bud formation of Saccharomyces cerevisiae [69] and hyphal growth, conidiation, and mitosis of Aspergillus nidulans [70]. Moreover, Rac1, another member of Ras superfamily, cooperates with p21-activated kinase Cla4, controlling the location of ROS, then in turn impacting the polarized growth and virulence of $V$. dahlia [71].

The similar expression trends of Ras-GAP and serine/threonine protein kinase during the detached leaves' infection mirror those from the stem extract treatment, which suggests that Ras-GAP and serine/threonine protein kinase may work in a similar model, or even in the same signal pathway, in $V$. dahliae. It has been shown in numerous studies that Ras-GAP-related Ras is essential for virulence or infection-related structure formation in $F$. graminearum, M. oryzae, and A. fumigatus [40-42], and its function involves serine/threonine protein kinases such as MAP kinase and sometimes protein kinase A (PKA) [72,73]. This is in support of our finding that Ras-GAP and serine/threonine protein kinase express more in response to elicitation with stem extracts and infection of detached leaves by the highly aggressive isolate than the weakly aggressive one. Meanwhile, a PKA catalytic subunit gene $V d P K A C 1$ was found to be important for conidia and microsclerotia production, as well as pathogenicity in $V$. dahliae [74]. All of this indicates that the small GTPase signaling pathway in $V$. dahliae, including Ras-GAP and serine/threonine protein kinase, may have an important role in the infection and morphogenesis processes related to pathogenicity, and may also play important roles in differential aggressiveness between isolates.

In M. oryzae, disruption of transcription factor Tup1 induced a loss of pathogenicity and an increase in glucan endo-1, 3-alpha-glucosidase's (MoAgn1) expression [75]. This indicates that a high activity of MoAgn1, controlled by the pathogenicity-related transcription factor Tup1, may be associated with low pathogenicity. Interestingly, a $\beta-1,6-$ endoglucanase gene, $\operatorname{Veg} B$, involved in degrading chitin and $\beta$-glucan, was also identified in $V$. dahliae. Single gene disruption did not significantly affect virulence compared to wild-type strains [76]. However, double-disruption mutants for both $V e g B$ and VdPKAC1 in $V$. dahliae showed higher virulence than the single mutant $V d P K A C 1$ [76], suggesting that VegB may negatively regulate the PKA-related signaling pathway's role in pathogenicity. In our work, the expression of endo-1, 3-alpha-glucosidase in $V$. dahliae also exhibited a transient increase in the weakly aggressive isolate. We hypothesized that the more aggressive $V$. dahliae isolate may have down-regulated the activity of endo-1, 3-alpha-glucosidase to accommodate the stress conditions in place during infection of the host.

In response to pathogen attacks, plants produce a great number of ROS that can induce DNA damage and restrict the expansion of pathogens [77]. In S. cerevisiae, homologues of RAD6 and RAD18 are involved in both the error-free post-replication DNA repair and the REV3-mediated mutagenesis pathways [78-84]. MMS2 is only involved in the error-free post-replication DNA repair mode [78]. All three genes involved in DNA repair showed an increased expression in response to potato extracts. Based on our results, DNA repair proteins could help $V$. dahliae to recover from DNA damage. This is in line with a RAD14 transient induction during transition from a less virulent to a more virulent state in $C$. albicans [68]. However, RAD51 showed a higher activity in weakly aggressive isolate than 
in highly aggressive one. We speculated that this protein might be more sensitive in lower aggressive isolates in response to DNA damage caused by plant defense mechanisms. In Helicobacter pylori, the disruption of a homologue of DNA-(apurinic or apyrimidinic site) lyase increased sensitivity to oxidative stress and reduced the colonization rate as compared to the wild type $[79,85]$. This indicates that DNA-(apurinic or apyrimidinic site) lyase is involved in aiding bacteria's survival under stress conditions and plays a role in its ability to colonize the host [85]. This is similar to our findings and indicates that this homologue in both isolates may help $V$. dahliae survive stress conditions, including DNA damage during infection. Ubiquitin-conjugating enzyme variant MMS2 transcripts contribute more in the highly aggressive isolate during the infection process. This is also similar to the findings on the human pathogen Paracoccidioides brasiliensis, where MMS2 was significantly elevated while infecting oral keratinocytes cell [86], indicating its function during infection.

In fungi, ROS are critical for the control of infection morphogenesis, sexual development, ascospore germination, and pathogenicity [87-89]. An NADPH oxidase for ROS production, VdNoxB, and a tetraspanin VdPls1, are both important for the transcription factor VdCrz1 activation towards penetration peg formation, then in controlling $V$. dahlia's virulence [90]. The Non-enzymatic ROS are produced in the mitochondria electron transport chain [91,92]. NADH-ubiquinone oxidoreductase (complex I) is the predominant gene responsible for the production of ROS in mitochondria of mammalian and bacterial cells [93-96]. Homeostasis of cellular ROS is maintained by scavenging systems which include the thioredoxin (Trx) system that consists mainly of Trx, Trx reductase (TrxR), and peroxidase (Prx) [97]. Our findings based on Trx and NADH-ubiquinone oxidoreductase in $V$. dahliae show that the ROS balance in $V$. dahliae responds differently in these two isolates and when exposed to different parts of the potato plant. The dramatic increase of TRX in the highly aggressive $V$. dahliae isolate, compared to the weakly aggressive one, suggests that the Trx function in reducing ROS and maintaining ROS balance in $V$. dahliae may be important for infection-related morphology and differentiation and therefore critical during infection. Previous studies showed that the expression of Trx or TrxR in Staphylococcus aureus, S. cerevisiae, Schizosaccharomyces pomb, C. albicans, and Cryptococcus neoformans, increased in response to various stress conditions such as oxidative or nitrosative stress [98-104]. Together, these findings suggest that the thioredoxin (Trx) ROS scavenging system may help the highly aggressive $V$. dahliae to respond to oxidative stress conditions imposed by plant defenses during colonization or at the time of infection. ROS produced by the NADH-ubiquinone oxidoreductase-mediated non-enzymatic system may also be involved in regulating spore germination during the pre-infection process. Therefore, ROS regulation may be important for pathogenicity in $V$. dahliae and possibly for the differential fitness of the highly aggressive isolate.

The genes involved in cellular metabolism are essential for maintaining nutrition support and normal growth in various organisms [31,33-35,44-51,62,63,105]. In V. dahliae, a MADS-box transcription factor VdMcm1 is critical for conidia and microsclerotia's formation, as well as cell-wall integrity and virulence, and its deletion also affects secondary metabolism in $V$. dahliae [106]. An ubiquitin ligase (E3) enzyme controlling secondary and lipid metabolism, named VdBre1, was identified in $V$. dahliae and is important for its virulence on cotton [107]. Another $V$. dahliae bZIP transcription factor Atf1 was also essential for virulence, and this protein controlled nitrogen metabolism in both $V$. dahliae and F. graminearum [108]. In our study, the expression of Serine 3-dehydrogenase, pyruvate dehydrogenase E1 component subunit beta, xanthine dehydrogenase, and myo-inositol dehydrogenase were upregulated in $V$. dahliae with potato extracts elicitation and during infection. VdPREG is a negative regulator for phosphorus acquisition, suggesting that the phosphorus acquisition pathway may be more activated in the highly than in the weakly aggressive $V$. dahliae isolate.

Several other studies show that these components of cellular metabolism are also important for virulence. D-serine metabolism is essential for virulence and regulation of 
several virulence factors in Staphylococcus saprophyticus [109]. This supports our results in $V$. dahliae that Serine 3-dehydrogenase has more activity in the highly aggressive isolate. The importance of pyruvate dehydrogenase E1 component subunit beta in the highly aggressive $V$. dahliae isolate during the pre-infection and infection stages may be suggested by its higher expression in response to stem extracts and during infection (Figure 5C,D). This is in line with the important role of Lipoamide dehydrogenase (Lpd), a member of the pyruvate dehydrogenase complex family, in the pathogenesis of Mycobacterium tuberculosis [110]. Plants produce antifungal compounds such as flavonoids to inhibit the activity of the pathogen's xanthine dehydrogenase in order to increase resistance to fungi and bacteria [52,111-114]. Even though there is no direct evidence showing that xanthine dehydrogenase is essential for pathogenicity in fungi, our results showed higher activity of xanthine dehydrogenase in the highly aggressive isolate than the weakly aggressive one (Figure 5E,F). This may indicate that xanthine dehydrogenase in a highly aggressive $V$. dahliae may overcome these inhibitors from plants and further play a role in colonization.

Our finding on myo-inositol dehydrogenase (Figure 5G,H) also suggests that the highly aggressive isolate utilizes this protein during the pre-infection and infection processes. This gene may play a function in helping $V$. dahliae in rhizopine utilization and viability for better colonization in the plant root, as previously shown in S. meliloti and $S$. fredii [33-35]. In N. crassa, the negative regulatory factor PREG can control the activity of transcription factor NUC-1, while NUC-1 can up-regulate the activity of the phosphorus acquisition enzymes encoding genes during phosphorus starvation conditions $[62,115,116]$. Interestingly, a homolog of N. crassa NUC was identified in V. dahliae as VdNUC-2, and is required for the pathogen's full virulence [117]. The lower activity of PREG in the highly aggressive $V$. dahliae isolate compared to the weakly aggressive one may indicate a higher activity of the phosphorus acquisition pathway. Phosphate acquisition is important for virulence in Ustilago maydis and C. neoformans and a connection was shown between phosphate acquisition and the PKA pathway controls the fungal virulence in both pathogens $[118,119]$. Our findings in PREG are consistent with their research as well as our hypothesis that a highly aggressive $V$. dahliae may suppress the up-regulation of PREG that is occurring in weakly aggressive $V$. dahliae, in order to achieve a higher activity in NUC1 and the phosphate acquisition pathway, as well as the serine/threonine protein kinases (such as PKA).

Finally, HAD-like hydrolase protein can be identified in different organisms, and studies reported their important roles in virulence in C. neoformans and in detoxification in E. coli and in S. cerevisiae $[66,67,120]$. Plants produce various secondary metabolites, proteases, and phytoalexins to ward off pathogens [121-125]. Plants also release some endogenous peptides to induce plant defense [126]. HAD superfamily hydrolase might help V. dahliae avoid plant toxins by detoxification and therefore play a role in virulence. This research is in line with our findings that HAD superfamily hydrolase may have a role to play in infection and differential pathogenic abilities of $V$. dahliae isolates.

\section{Materials and Methods}

\subsection{V. dahliae Isolates}

Two V. dahliae isolates, Vs06-07 and Vd1396-9, a weakly and highly aggressive isolate, respectively $[127,128]$, were selected for this study. Both isolates were cultured on potato dextrose agar (PDA) $24 \pm 0.5^{\circ} \mathrm{C}$ for 14 days.

\subsection{Pathogenicity Tests of $V$. dahliae Isolates}

Kennebec, a susceptible potato cultivar to $V$. dahliae [127], was used for the detached leaves inoculation and pathogenicity tests. Plants were grown in a mixture of sand, soil, and peat moss with a ratio of $16: 4: 1$, under a day/light temperature regimen of $22 / 18{ }^{\circ} \mathrm{C}$ and a photoperiod of $16 / 8 \mathrm{~h}$.

Assessment of the pathogenicity of both $V$. dahliae isolates was performed on potato cv. Kennebec as described by Zhu, Soliman [24]. Briefly, three Kennebec plants (3-week-old) 
were trimmed at the root tips and placed in the conidia suspension $\left(10^{6}\right.$ conidia $\left./ \mathrm{mL}\right)$ of the weakly or highly aggressive $V$. dahliae isolates, then planted in 6-inch pots with a pasteurized mixture of sand, soil, and peat moss (16:4:1). The total area under disease progress curves (AUDPC) of disease severity and percentage of infection were evaluated as described by Zhu, Soliman [24].

\subsection{Gene Selection and Primers' Design}

Fifteen genes were selected based on proteomic and subtractive hybridization/cDNAAFLP analyses of weakly and highly aggressive isolates in previous work [22,23]. These include: the genes encoding Ras-GAP like protein (VDAG_01012), pyruvate dehydrogenase E1 component subunit beta (VdPDHB) (VDAG_01642), DNA-(apurinic or apyrimidinic site) lyase (DNA AP lyase) (VDAG_02445), glucan endo-1,3-alpha-glucosidase agn1 (VDAG_04101), thioredoxin (VdTRX) (VDAG_04529), serine/threonine protein kinase (VDAG_04632), ubiquitin-conjugating enzyme variant MMS2 (VDAG_05365), nuc-1 negative regulatory protein preg (VdPREG) (VDAG_06766), xanthine dehydrogenase (VDAG_07735), myo-inositol 2-dehydrogenase (VDAG_08205), HAD-superfamily hydrolase (VDAG_08490), DNA repair protein RAD51 (VDAG_08796), Wos2 (VDAG_08865), NADH-ubiquinone oxidoreductase (VDAG_09026), and serine 3-dehydrogenase (VDAG_ 09532). Primer pairs for the target genes were designed based on the sequences from Verticillium comparative genomic project available at the Broad Institute (https: / www. broadinstitute.org/scientific-community/science/projects/fungal-genome-initiative/verticilliumcomparative-genomics-pro (accessed on 7 March 2021)). The Histone H3 gene (VDAG_10035) was used as a housekeeping gene [24] (Table 1).

Table 1. Primers used in RT-qPCR for amplifying the target genes.

\begin{tabular}{|c|c|c|c|c|}
\hline Primer's Name & Primer Sequence & $\operatorname{Tm}\left({ }^{\circ} \mathrm{C}\right)$ & Accession Number & Amplification Length (bp) \\
\hline Ras-GAP like protein-F & ACGCTGTCCAACCTTCAC & 53 & VDAG_01012 & \multirow{2}{*}{273} \\
\hline Ras-GAP like protein- $\mathrm{R}$ & GTTGATCTTGTCCCAGTCG & 52.7 & VDAG_01012 & \\
\hline Pyruvate dehydrogenase E1 component subunit beta-F & CTTCGGCGACAAGAGGGT & 58.1 & VDAG_01642 & \multirow{2}{*}{283} \\
\hline Pyruvate dehydrogenase E1 component subunit beta- $R$ & GGGAATGCTGCCATACCAC & 58.2 & VDAG_01642 & \\
\hline DNA-(apurinic or apyrimidinic site) lyase-F & CCGGCTGGGACGTTTA & 55.1 & VDAG_02445 & \multirow{2}{*}{152} \\
\hline DNA-(apurinic or apyrimidinic site) lyase-R & GCGGAATCTGGTGGTTG & 54.2 & VDAG_02445 & \\
\hline glucan endo-1,3-alpha-glucosidase agn1-F & GCCTTCGGAAACCTCAAT & 54.6 & VDAG_04101 & \multirow{2}{*}{307} \\
\hline glucan endo-1,3-alpha-glucosidase agn1-R & CTCССATGAACTCATACGC & 53.2 & VDAG_04101 & \\
\hline Thioredoxin (VdTRX)-F & GCTGCTCCTGTTTATGCCTTTCCA & 66.8 & VDAG_04529 & \multirow{2}{*}{145} \\
\hline Thioredoxin (VdTRX)-R & GAGGTTATGCGGCTTGTTCGT & 61.8 & VDAG_04529 & \\
\hline serine/threonine protein kinase-F & GGTGGGTGCGGTCAAATA & 56.9 & VDAG_04632 & \multirow{2}{*}{272} \\
\hline serine/threonine protein kinase- $\mathrm{R}$ & AGGCATCCGTAGCACGAC & 56.2 & VDAG_04632 & \\
\hline Ubiquitin-conjugating enzyme variantMMS2-F & CATCCTCGGTCCTCCTCA & 55.5 & VDAG_05365 & \multirow{2}{*}{235} \\
\hline Ubiquitin-conjugating enzyme variantMMS2-R & CGCCATGTACCTCCTGATC & 55.6 & VDAG_05365 & \\
\hline VdPREG-F & GGGAATCTGACTAGGTTTCATT & 54.7 & VDAG_06766 & \multirow{2}{*}{227} \\
\hline VdPREG-R & GAGTCGGACAGACCTTTGG & 54.7 & VDAG_06766 & \\
\hline Xanthine dehydrogenase-F & GGCTGCTGCATGGATAAG & 54.4 & VDAG_07735 & \multirow{2}{*}{227} \\
\hline Xanthine dehydrogenase- $R$ & CCGACAAATACCGACACG & 54.9 & VDAG_07735 & \\
\hline myo-inositol 2-dehydrogenase-F & AGTCTGGCATCGACAATAAC & 52.3 & VDAG_08205 & \multirow{2}{*}{192} \\
\hline myo-inositol 2-dehydrogenase- $R$ & GCAGTCTCAACACGCAAA & 52.6 & VDAG_08205 & \\
\hline HAD-superfamily hydrolase-F & AGCCCGACCCTGCCATCTA & 62.6 & VDAG_08490 & \multirow{2}{*}{225} \\
\hline HAD-superfamily hydrolase-R & GGAACTCTTGCCAGTCCTTCA & 59.2 & VDAG_08490 & \\
\hline DNA repair protein RAD51-F & ATGGTGAGGGCGAGATGG & 58.3 & VDAG_08796 & \multirow{2}{*}{153} \\
\hline DNA repair protein RAD51-R & GGGTGTAAGCGACGGATT & 55.4 & VDAG_08796 & \\
\hline VdWos2-F & GTCTGCTACCAAGGCAACTCC & 58.7 & VDAG_08865 & \multirow{2}{*}{227} \\
\hline VdWos2-R & TCTCCTCCGTGTCAATCTCG & 58.1 & VDAG_08865 & \\
\hline
\end{tabular}


Table 1. Cont.

\begin{tabular}{cccccc}
\hline Primer's Name & Primer Sequence & Tm ( ${ }^{\circ}$ C) & Accession Number & Amplification Length (bp) \\
\hline NADH-ubiquinone oxidoreductase-F & ATCGGGGCGGGTCTCATT & 62.1 & VDAG_09026 \\
\hline NADH-ubiquinone oxidoreductase-R & CCTTCGGCAGGCTTCTCC & 60.3 & VDAG_09026 \\
\hline Serine 3-dehydrogenase-F & ACTTGGGCATTAAGGTGGTC & 56.5 & VDAG_09532 \\
\hline Serine 3-dehydrogenase-R & CATCGCAGTCAGTTGTCGTAG & 56.6 & VDAG_09532 \\
\hline His3-F (Zhu et al., 2017) & ATGGCTCGCACTAAGCAA & 54.8 & VDAG_10035 \\
\hline His3-R (Zhu et al., 2017) & TGAAGTCCTGGGCAATCT & 52.7 & VDAG_10035 & 238 \\
\hline
\end{tabular}

Note: The accession numbers of the genes are available in the Verticillium comparative genomic project of the Broad Institute (https: / www. broadinstitute.org/scientific-community/science/projects/fungal-genome-initiative/verticillium-comparative-genomics-pro, accessed on 7 March 2021).

\subsection{Elicitation and Inoculation Methods}

The elicitation of both $V$. dahliae isolates with potato extracts was done following the protocol described by Zhu, Soliman [24], and the preparation of potato extracts was done following the protocol described by El-Bebany, Henriquez [23]. Briefly, one milliliter of 108 conidia of both isolates were added to $100 \mathrm{ml}$ Czapek-Dox Broth (CDB) liquid media (Difco Laboratories, Sparks, MD, USA) and incubated at $24 \pm 0.5^{\circ} \mathrm{C}$ for 7 days. One milliliter of prepared potato leaf, stem, and root extracts was added into CDB medium, and mycelium samples were harvested after 7 days of incubation in the same conditions. Three biological replicates were prepared for each treatment.

The detached leaves infection was done using a protocol described by Zhu, Soliman [24]. V. dahliae isolates Vd1396-9 and Vs06-07 were grown in PDA at $24 \pm 0.5^{\circ} \mathrm{C}$ for 21 days. Conidia were then collected and diluted in a concentration of $3 \times 10^{7}$ coni$\mathrm{dia} / \mathrm{mL}$. Clones of Potato cv. Kennebec plants were then grown in LA4 soil mix (SunGro Horticulture, Agawam, MA 01001, USA) for 4 weeks, then one leaf was cut, placed into $1 \mathrm{~mL}$ of the conidia suspension, and maintained under a photoperiod of $16 / 8 \mathrm{~h}$ at $24{ }^{\circ} \mathrm{C}$. Sterilized water, was used as a control for inoculation. Four to six individual detached leaves, each from separate plants were pooled as one sample. This was repeated three times for each treatment at each time-point $(1,3,5$, and 8 days after inoculation (DAI)). Samples representing the three biological replicates were immediately frozen in liquid nitrogen and stored at $-80^{\circ} \mathrm{C}$ until used for RNA extraction.

\subsection{RNA Extraction and RT-qPCR}

Total RNA was extracted from mycelium (100 mg), and potato detached leaves (100 mg) using the Omega Fungal RNA kit (Omega Moi-Tek, Inc., Norcross, GA, USA), following the manufacturer's protocol. The first strand cDNA was synthesized from $5 \mu \mathrm{g}$ total RNA following the manufacturer's protocol of the Superscript first strand synthesis kit (Life Technologies, Carlsbad, CA, USA).

Quantitative Real-Time PCR was performed for each target gene as well as for the reference gene using SsoFast EvaGreen Super mix (Bio-Rad Lab, Hercules, PA, USA) following the manufacturer recommendations. The $2^{-\Delta \Delta C T}$ method [129] has been used to evaluate expression of the above mentioned genes.

\subsection{Statistical Analysis}

Pathogenicity data and gene expression under different treatments were analyzed with PROC MIXED in SAS Statistical Analysis Software (SAS Institute, Cary, NC, USA; release 9.1 for Windows). The normality of all data (three biological replicates, in infection experiments each representing 4-6 leaves samples from 4-6 separate plants) was determined with PROC UNIVARIATE, and analysis showed that data from different treatments were all qualified for normal distribution with Shapiro-Wilk test $(>0.9)$ and $p$ value $(>0.05)$, and qualified for homogeneity based on residuals comparison to studentized residuals critical values [130]. Log10 transformation was applied to some sets of gene expression data statistical analysis. The macro PDMIX800.sas [53], $\alpha=0.05$ was applied to mean values separated by least 
squared means, and into grouped letter results. Mean values $(n=3)$ with the same letters indicate non-significant differences from each other $(p<0.05)$ in different sets of experiments.

\section{Conclusions}

In conclusion, the expression level of most of the genes we tested increased in both weakly and highly aggressive isolates in response to treatment with the various potato extracts. The metabolism of pyruvate, purines and pyrimidines, inositol and inositol phosphate, and phosphorus acquisition may be activated more in the highly aggressive isolate than in the weakly aggressive one in response to the various potato extracts (Figure 7). The genes involved in ROS production (NADH-ubiquinone oxidoreductase) and small GTPase signaling pathway (including Ras-GAP and serine/threonine protein kinase) were also elevated in the highly aggressive isolate more than the weakly aggressive one when exposed to potato stem extracts, suggesting a higher activity in these pathways (Figure 7). During infection of potato detached leaves, there were more up-regulated genes in the highly aggressive isolate than the weak aggressive one. These genes include key elements in the small GTPase signaling pathway, which include Ras-GAP and serine/threonine protein kinase, DNA damage repair, ROS production and cleavage, cellular metabolism, and detoxification. These results suggest an important role for all of these pathways during infection. This study provides a detailed follow up on the temporal expression of genes identified in our previous studies [22,23]. Together with more recent functional analyses of selected genes and interaction with host defense components [21,24,131], this study provides another background to reflect on which metabolic reactions contribute to disease, and which ones rather contribute to less disease or lack of it. The work ahead should put emphasis on the spatiotemporal expression of these genes during these interactions in order to fine-tune the expression map of genes that are important for the pathogen to invade its hosts. Further functional analyses of these genes should validate their involvement in an integrated picture of the arsenal that $V$. dahliae uses against its most economic hosts. This will no doubt help us to the right direction of future management tools against Verticillium wilt disease.

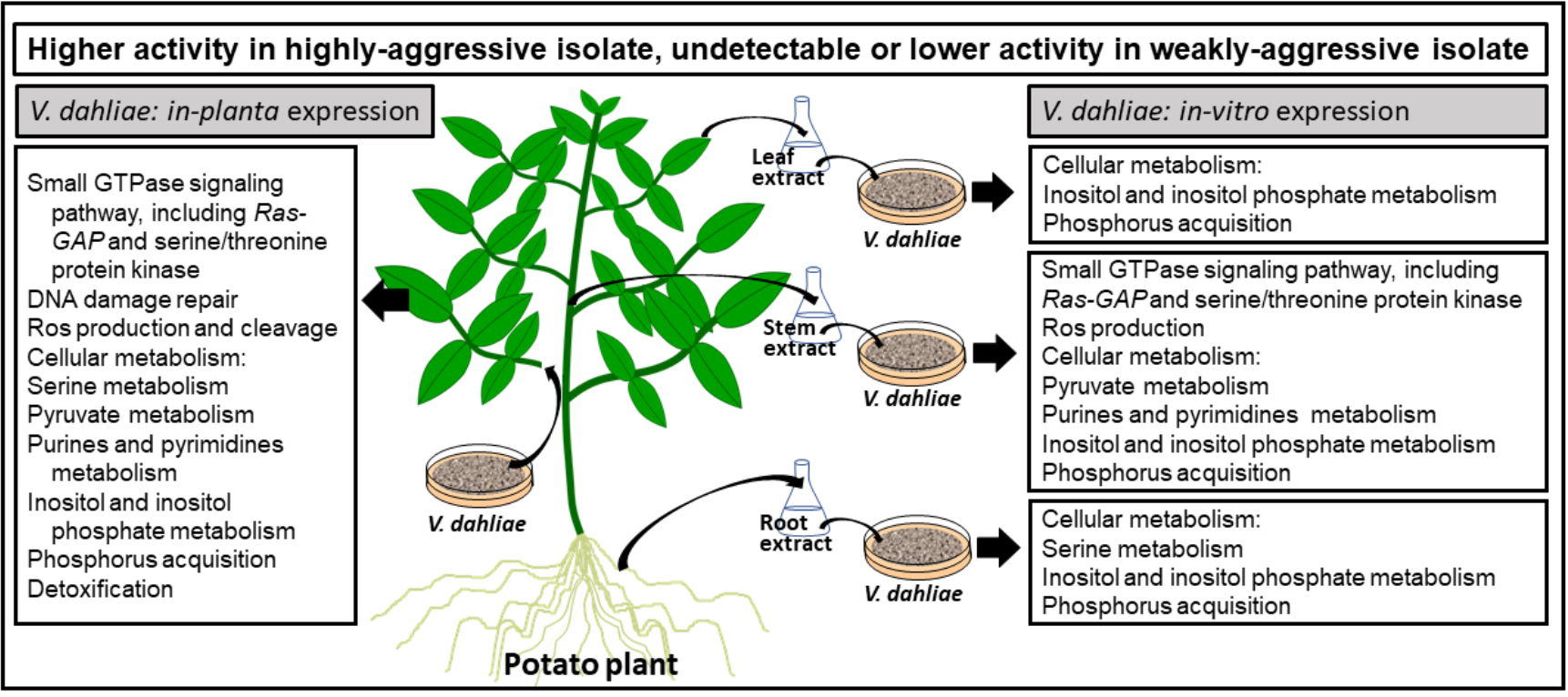

Figure 7. Potential involvement of pathways in response to potato extracts from various tissues and infection. 
Supplementary Materials: The supplementary files are available online at https:/ /www.mdpi.com/ article/10.3390/pathogens10050510/s1, Supplementary Figure S1: Signal peptides prediction of Glucan en-do-1,3-alpha-glucosidase agn1 by SignalP 5.0. Protein sequences were obtained from Verticillium comparative genomic project of the Broad Institute (https:/ / www.broadinstitute.org/scientificcommunity/science/projects / fungal-genome-initiative/verticillium-comparative-genomics-pro, accessed on 7 March 2021). Table S1: Signal peptides prediction by SignalP 5.0. Table S2: Effector prediction by Effector $1.0 \& 2.0$.

Author Contributions: Conceptualization, F.D. and X.Z.; methodology, X.Z., M.S., L.R.A., A.A.; validation, X.Z., M.S., L.R.A.; formal analysis, X.Z., M.S.; resources, F.D.; data curation, X.Z., M.S., L.R.A.; writing—original draft preparation, X.Z., M.S.; writing—review and editing, A.A. and F.D.; supervision, F.D.; project administration, F.D.; funding acquisition, F.D. All authors have read and agreed to the published version of the manuscript.

Funding: This research was funded by a Discovery grant to F.D. from the Natural Sciences and Engineering Research Council of Canada.

Institutional Review Board Statement: Not applicable.

Informed Consent Statement: Not applicable.

Data Availability Statement: The accession numbers of the genes are available in the Verticillium comparative genomic project of the Broad Institute (https://www.broadinstitute.org/scientificcommunity/science/projects / fungal-genome-initiative/verticillium-comparative-genomics-pro, accessed on 7 March 2021).

Acknowledgments: The authors acknowledge technical support from Pawanpuneet Rehal and Hassna Alkher.

Conflicts of Interest: The authors declare no conflict of interest. The funders had no role in the design of the study; in the collection, analyses, or interpretation of data; in the writing of the manuscript, or in the decision to publish the results.

\section{References}

1. Pegg, G.F.; Brady, B.L. Verticillium Wilts; CABI: Wallingford, UK, 2002.

2. Krikun, J.; Orion, D. Verticillium wilt of potato: Importance and control. Phytoparasitica 1979, 7, 107-116. [CrossRef]

3. Molina, O.I.; Tenuta, M.; El Hadrami, A.; Buckley, K.; Cavers, C.; Daayf, F. Potato Early Dying and Yield Responses to Compost, Green Manures, Seed Meal and Chemical Treatments. Am. J. Potato Res. 2014, 91, 414-428. [CrossRef]

4. Rowe, R.C.; Powelson, M.L. Potato Early Dying: Management Challenges in a Changing Production Environment. Plant Dis. 2002, 86, 1184-1193. [CrossRef] [PubMed]

5. Nnodu, E.C.; Harrison, M.D. The relationship betweenVerticillium albo-atrum inoculum density and potato yield. Am. J. Potato Res. 1979, 56, 11-25. [CrossRef]

6. Wilhelm, S. Longevity of the Verticillium wilt fungus in the laboratory and field. Phytopathology 1955, 45, 180-181.

7. Olsson, S.; Nordbring-Hertz, B. Microsclerotial germination of Verticillium dahliae as affected by rape rhizosphere. FEMS Microbiol. Ecol. 1985, 1, 293-299. [CrossRef]

8. Fradin, E.F.; Thomma, B.P.H.J. Physiology and molecular aspects of Verticillium wilt diseases caused by V. dahliae and V. albo-atrum. Mol. Plant Pathol. 2006, 7, 71-86. [CrossRef]

9. Bowers, J. Infection and Colonization of Potato Roots by Verticillium dahliae as Affected by Pratylenchus penetrans and P. crenatus. Phytopathology 1996, 86, 614-621. [CrossRef]

10. Daayf, F. Verticillium wilts in crop plants: Pathogen invasion and host defence responses. Can. J. Plant Pathol. 2014, 37, 8-20. [CrossRef]

11. Smit, F.; Dubery, I.A. Cell wall reinforcement in cotton hypocotyls in response to a Verticillium dahliae elicitor. Phytochemistry 1997, 44, 811-815. [CrossRef]

12. Griffiths, D.A. The development of lignitubers in roots after infection by Verticillium dahliae Kleb. Can. J. Microbiol. 1971, 17, 441-444. [CrossRef] [PubMed]

13. Gayoso, C.; Pomar, F.; Novo-Uzal, E.; Merino, F.; de Ilárduya, Ó.M. The Ve-mediated resistance response of the tomato to Verticillium dahliae involves $\mathrm{H} 2 \mathrm{O}$ 2, peroxidase and lignins and drives PALgene expression. BMC Plant Biol. 2010, 10, 232. [CrossRef] [PubMed]

14. Debode, J.; Clewes, E.; De Backer, G.; Höfte, M. Lignin is involved in the reduction of Verticillium dahliae var. longisporum inoculum in soil by crop residue incorporation. Soil Biol. Biochem. 2005, 37, 301-309. [CrossRef]

15. Daayf, F.; Nicole, M.; Boher, B.; Pando, A.; Geiger, J.P. Early vascular defense reactions of cotton roots infected with a defoliating mutant strain of Verticillium dahliae. Eur. J. Plant Pathol. 1997, 103, 125-136. [CrossRef] 
16. Mace, M.; Stipanovic, R.; Bell, A. Relation between sensitivity to terpenoid phytoalexins and virulence to cotton of Verticillium dahliae strains. Pestic. Biochem. Physiol. 1990, 36, 79-82. [CrossRef]

17. Mace, M.E.; Stipanovic, R.D.; Bell, A.A. Histochemical localization of desoxyhemigossypol, a phytoalexin in Verticillium dahliae -infected cotton stems. New Phytol. 1989, 111, 229-232. [CrossRef] [PubMed]

18. Robb, J.; Brisson, J.D.; Busch, L.; Lu, B.C. Ultrastructure of wilt syndrome caused by Verticillium dahliae. VII. Correlated light and transmission electron microscope identification of vessel coatings and tyloses. Can. J. Bot. 1979, 57, 822-834. [CrossRef]

19. Jiménez-Díaz, R.M.; Cirulli, M.; Bubici, G.; Jiménez-Gasco, M.D.M.; Antoniou, P.P.; Tjamos, E.C. Verticillium Wilt, A Major Threat to Olive Production: Current Status and Future Prospects for its Management. Plant Dis. 2012, 96, 304-329. [CrossRef]

20. Davis, J.R. Influence of Continuous Cropping of Several Potato Clones on the Epidemiology of Verticillium Wilt of Potato. Phytopathology 1994, 84, 207-214. [CrossRef]

21. El Hadrami, A.; Islam, M.; Adam, L.R.; Daayf, F. A cupin domain-containing protein with a quercetinase activity (VdQase) regulates Verticillium dahliae's pathogenicity and contributes to counteracting host defenses. Front. Plant Sci. 2015, 6, 440. [CrossRef]

22. El-Bebany, A.F.; Rampitsch, C.; Daayf, F. Proteomic analysis of the phytopathogenic soilborne fungus Verticillium dahliae reveals differential protein expression in isolates that differ in aggressiveness. Proteomics 2010, 10, 289-303. [CrossRef] [PubMed]

23. El-Bebany, A.F.; Henriquez, M.A.; Badawi, M.; Adam, L.R.; El Hadrami, A.; Daayf, F. Induction of putative pathogenicity-related genes in Verticillium dahliae in response to elicitation with potato root extracts. Env.. Exp. Bot. 2011, 72, 251-257. [CrossRef]

24. Zhu, X.; Soliman, A.; Islam, M.R.; Adam, L.R.; Daayf, F. Verticillium dahliae's Isochorismatase hydrolase is a virulence factor that contributes to interference with potato's Salicylate and Jasmonate defense signaling. Front. Plant Sci. 2017, 8, 399. [CrossRef]

25. Santos, B.; Martín-Cuadrado, A.B.; De Aldana, C.R.V.; Del Rey, F.; Pérez, P. Rho4 GTPase Is Involved in Secretion of Glucanases during Fission Yeast Cytokinesis. Eukaryot. Cell 2005, 4, 1639-1645. [CrossRef]

26. Dekker, N.; Speijer, D.; Grün, C.H.; Berg, M.V.D.; De Haan, A.; Hochstenbach, F. Role of the $\alpha$-Glucanase Agn1p in Fission-Yeast Cell Separation. Mol. Biol. Cell 2004, 15, 3903-3914. [CrossRef] [PubMed]

27. García, I.; Jiménez, D.; Martín, V.; Durán, A.; Sánchez, Y. The $\alpha$-glucanase Agn1p is required for cell separation in Schizosaccharomyces pombe. Biol. Cell 2005, 97, 569-576. [CrossRef]

28. Villalobos-Duno, H.; San-Blas, G.; Paulinkevicius, M.; Sánchez-Martín, Y.; Nino-Vega, G. Biochemical Characterization of Paracoccidioides brasiliensis $\alpha-1,3$-Glucanase Agn1p, and Its Functionality by Heterologous Expression in Schizosaccharomyces pombe. PLoS ONE 2013, 8, e66853. [CrossRef]

29. Hercyk, B.S.; Onwubiko, U.N.; Das, M.E. Coordinating septum formation and the actomyosin ring during cytokinesis in Schizosaccharomyces pombe. Mol. Microbiol. 2019, 112, 1645-1657. [CrossRef]

30. Tsui, C.; Raguraj, A.; Pickart, C.M. Ubiquitin binding site of the ubiquitin E2 variant (UEV) protein Mms2 is required for DNA damage tolerance in the yeast RAD6 pathway. J. Biol. Chem. 2005, 280, 19829-19835. [CrossRef]

31. Tchigvintsev, A.; Singer, A.; Brown, G.; Flick, R.; Evdokimova, E.; Tan, K.; Gonzalez, C.F.; Savchenko, A.; Yakunin, A.F. Biochemical and Structural Studies of Uncharacterized Protein PA0743 from Pseudomonas aeruginosa Revealed NAD+-dependent l-Serine Dehydrogenase. J. Biol. Chem. 2012, 287, 1874-1883. [CrossRef]

32. Tomazett, M.V.; Baeza, L.C.; Paccez, J.D.; Parente-Rocha, J.A.; Ribeiro-Dias, F.; Soares, C.M.D.A. Identification and characterization of Paracoccidioides lutzii proteins interacting with macrophages. Microbes Infect. 2019, 21, 401-411. [CrossRef]

33. Galbraith, M.P.; Feng, S.F.; Borneman, J.; Triplett, E.W.; de Bruijn, F.J.; Rossbachl, S. A functional myo-inositol catabolism pathway is essential for rhizopine utilization by Sinorhizobium meliloti. Microbiology 1998, 144, 2915-2924. [CrossRef]

34. Berman, T.; Magasanik, B. The Pathway of myo-Inositol Degradation in Aerobacter aerogenes Dehydrogenation and Dehydration. J. Biol. Chem. 1966, 241, 800-806. [CrossRef]

35. Jiang, G.; Krishnan, A.H.; Kim, Y.W.; Wacek, T.J.; Krishnan, H.B. A functional myo-inositol dehydrogenase gene is required for efficient nitrogen fixation and competitiveness of Sinorhizobium fredii USDA191 to nodulate soybean (Glycine max [L.] Merr.). J. Bacteriol. 2001, 183, 2595-2604. [CrossRef] [PubMed]

36. Boguski, M.S.; McCormick, F. Proteins regulating Ras and its relatives. Nat. Cell Biol. 1993, 366, 643-654. [CrossRef]

37. Scheffzek, K.; Ahmadian, M.R.; Kabsch, W.; Wiesmüller, L.; Lautwein, A.; Schmitz, F.; Wittinghofer, A. The Ras-RasGAP complex: Structural basis for GTPase activation and its loss in oncogenic Ras mutants. Science 1997, 277, 333-339. [CrossRef] [PubMed]

38. Dickman, M.B.; Yarden, O. Serine/threonine protein kinases and phosphatases in filamentious fungi. Fungal Genet. Biol. 1999, 26, 99-117. [CrossRef]

39. Manser, E.; Leung, T.; Salihuddin, H.; Zhao, Z.-S.; Lim, L. A brain serine/threonine protein kinase activated by Cdc42 and Rac1. Nat. Cell Biol. 1994, 367, 40-46. [CrossRef] [PubMed]

40. Park, G.; Xue, C.; Zhao, X.; Kim, Y.; Orbach, M.; Xu, J.-R. Multiple Upstream Signals Converge on the Adaptor Protein Mst50 in Magnaporthe grisea. Plant Cell 2006, 18, 2822-2835. [CrossRef]

41. Ding, S.; Zhou, X.; Zhao, X.; Xu, J.-R. The PMK1 MAP Kinase Pathway and Infection-Related Morphogenesis. In Advances in Genetics, Genomics and Control of Rice Blast Disease; Metzler, J.B., Ed.; Springer: Berlin/Heidelberg, Germany, 2009 ; pp. 13-21.

42. Bluhm, B.H.; Zhao, X.; Flaherty, J.E.; Xu, J.-R.; Dunkle, L.D. RAS2 Regulates Growth and Pathogenesis in Fusarium graminearum. Mol. Plant-Microbe Interact. 2007, 20, 627-636. [CrossRef] [PubMed]

43. Muñoz, M.J.; Bejarano, E.R.; Daga, R.R.; Jimenez, J. The identification of Wos2, a p23 homologue that interacts with Wee1 and $\mathrm{Cdc} 2$ in the mitotic control of fission yeasts. Genetics 1999, 153, 1561-1572. [PubMed] 
44. Seifert, F.; Ciszak, E.; Korotchkina, L.; Golbik, R.; Spinka, M.; Dominiak, P.; Sidhu, S.; Brauer, J.; Patel, M.S.; Tittmann, K. Phosphorylation of serine 264 impedes active site accessibility in the E1 component of the human pyruvate dehydrogenase multienzyme complex. Biochemistry 2007, 46, 6277-6287. [CrossRef]

45. Lessard, I.; Perham, R.N. Expression in Escherichia coli of genes encoding the E1 alpha and E1 beta subunits of the pyruvate dehydrogenase complex of Bacillus stearothermophilus and assembly of a functional E1 component (alpha 2 beta 2) in vitro. J. Biol. Chem. 1994, 269, 10378-10383. [CrossRef]

46. Dallo, S.F.; Kannan, T.R.; Blaylock, M.W.; Baseman, J.B. Elongation factor Tu and E1 $\beta$ subunit of pyruvate dehydrogenase complex act as fibronectin binding proteins in Mycoplasma pneumoniae. Mol. Microbiol. 2002, 4, 1041-1051. [CrossRef] [PubMed]

47. Kato, M.; Wynn, M.R.; Chuang, L.J.; Tso, C.S.; Machius, M.; Li, J.; Chuang, T.D. Structural basis for inactivation of the human pyruvate dehydrogenase complex by phosphorylation: Role of disordered phosphorylation loops. Structure 2008, 16, 1849-1859. [CrossRef]

48. Bittner, F.; Oreb, M.; Mendel, R.R. ABA3 is a molybdenum cofactor sulfurase required for activation of aldehyde oxidase and xanthine dehydrogenase in Arabidopsis thaliana. J. Biol. Chem. 2001, 276, 40381-40384. [CrossRef]

49. Engerson, T.D.; McKelvey, T.G.; Rhyne, D.B.; Boggio, E.B.; Snyder, S.J.; Jones, H.P. Conversion of xanthine dehydrogenase to oxidase in ischemic rat tissues. J. Clin. Investig. 1987, 6, 1564-1570. [CrossRef]

50. Enroth, C.; Eger, B.T.; Okamoto, K.; Nishino, T.; Nishion, T.; Pai, E.F. Crystal structures of bovine milk xanthine dehydrogenase and xanthine oxidase: Structure-based mechanism of conversion. Proc. Nat. Acad. Sci. USA 2000, 20, 10723-10728. [CrossRef]

51. Hille, R.; Nishino, T. Xanthine oxidase and xanthine dehydrogenase. FASEB J. 1995, 9, 995-1003. [CrossRef] [PubMed]

52. Khobragade, C.N.; Bodade, R.G.; Shinde, M.S.; Jaju, D.R.; Bhosle, R.B.; Dawane, B.S. Microbial and xanthine dehydrogenase inhibitory activity of some flavones. J. Enzym. Inhib. Med. Chem. 2008, 23, 341-346. [CrossRef]

53. Saxton, A. A macro for converting mean separation output to letter groupings in Proc Mixed. In Proceedings of the 23rd SAS Users Group International, Nashville, TN, USA, 22-25 March 1998; pp. 1243-1246.

54. Armenteros, J.J.A.; Tsirigos, K.D.; Sønderby, C.K.; Petersen, T.N.; Winther, O.; Brunak, S.; Von Heijne, G.; Nielsen, H. SignalP 5.0 improves signal peptide predictions using deep neural networks. Nat. Biotechnol. 2019, 37, 420-423. [CrossRef]

55. Sperschneider, J.; Dodds, P.N.; Gardiner, D.M.; Singh, K.B.; Taylor, J.M. Improved prediction of fungal effector proteins from secretomes with EffectorP 2.0. Mol. Plant Pathol. 2018, 19, 2094-2110. [CrossRef]

56. Sperschneider, J.; Gardiner, D.M.; Dodds, P.N.; Tini, F.; Covarelli, L.; Singh, K.B.; Manners, J.M.; Taylor, J.M. EffectorP: Predicting fungal effector proteins from secretomes using machine learning. New Phytol. 2016, 210, 743-761. [CrossRef]

57. Davies, A.; Masson, J.-Y.; Mcllwraith, M.J.; Stasiak, A.Z.; Stasiak, A.; Venkitaraman, A.R.; West, S.C. Role of BRCA2 in Control of the RAD51 Recombination and DNA Repair Protein. Mol. Cell 2001, 7, 273-282. [CrossRef]

58. Ulrich, H.D.; Jentsch, S. Two RING finger proteins mediate cooperation between ubiquitin-conjugating enzymes in DNA repair. EMBO J. 2000, 19, 3388-3397. [CrossRef]

59. Hofmann, R.M.; Pickart, C.M. Noncanonical MMS2-Encoded Ubiquitin-Conjugating Enzyme Functions in Assembly of Novel Polyubiquitin Chains for DNA Repair. Cell 1999, 96, 645-653. [CrossRef]

60. Nakamura, J.; A Swenberg, J. Endogenous apurinic/apyrimidinic sites in genomic DNA of mammalian tissues. Cancer Res. 1999, 59, 2522-2526. [PubMed]

61. Aburatani, H.; Hippo, Y.; Ishida, T.; Takashima, R.; Matsuba, C.; Kodama, T.; Takao, M.; Yasui, A.; Yamamoto, K.; Asano, M. Cloning and characterization of mammalian 8-hydroxyguanine-specific DNA glycosylase/apurinic, apyrimidinic lyase, a functional mutM homologue. Cancer Res. 1997, 57, 2151-2156. [PubMed]

62. Peleg, Y.; Addison, R.; Aramayo, R.; Metzenberg, R.L. Translocation ofNeurospora crassaTranscription Factor NUC-1 into the Nucleus Is Induced by Phosphorus Limitation. Fungal Genet. Biol. 1996, 20, 185-191. [CrossRef]

63. Kang, S. Functional domains of the transcriptional activator NUC-1 in Neurospora crassa. Gene 1993, 130, 259-264. [CrossRef]

64. Burroughs, A.M.; Allen, K.N.; Dunaway-Mariano, D.; Aravind, L. Evolutionary genomics of the HAD superfamily: Understanding the structural adaptations and catalytic diversity in a superfamily of phosphoesterases and allied enzymes. J. Mol. Biol. 2006, 361, 1003-1034. [CrossRef] [PubMed]

65. Koonin, E.V.; Tatusov, R.L. Computer analysis of bacterial haloacid dehalogenases defines a large superfamily of hydrolases with diverse specificity: Application of an iterative approach to database search. J. Mol. Biol. 1994, 244, 125-132. [CrossRef] [PubMed]

66. Kuznetsova, E.; Nocek, B.; Brown, G.; Makarova, K.S.; Flick, R.; Wolf, Y.I.; Khusnutdinova, A.; Evdokimova, E.; Jin, K.; Tan, K.; et al. Functional diversity of haloacid dehalogenase superfamily phosphatases from Saccharomyces cerevisiae biochemical, structural, and evolutionary insights. J. Biol. Chem. 2015, 290, 18678-18698. [CrossRef] [PubMed]

67. Kuznetsova, E.; Proudfoot, M.; Gonzalez, C.F.; Brown, G.; Omelchenko, M.V.; Borozan, I.; Carmel, L.; Wolf, Y.I.; Mori, H.; Savchenko, A.V.; et al. Genome-wide analysis of substrate specificities of the Escherichia coli haloacid dehalogenase-like phosphatase family. J. Biol. Chem. 2006, 281, 36149-36161. [CrossRef]

68. Nantel, A.; Dignard, D.; Bachewich, C.; Harcus, D.; Marcil, A.; Bouin, A.-P.; Sensen, C.W.; Hogues, H.; Hoog, M.V.H.; Gordon, P.; et al. Transcription Profiling ofCandida albicansCells Undergoing the Yeast-to-Hyphal Transition. Mol. Biol. Cell 2002, 13, 3452-3465. [CrossRef] [PubMed]

69. Cvrcková, F.; Nasmyth, K. Yeast G1 cyclins CLN1 and CLN2 and a GAP-like protein have a role in bud formation. EMBO J. 1993, 12, 5277-5286. [CrossRef] 
70. Harispe, L.; Portela, C.; Scazzocchio, C.; Peñalva, M.A.; Gorfinkiel, L. Ras GTPase-Activating Protein Regulation of Actin Cytoskeleton and Hyphal Polarity in Aspergillus nidulans. Eukaryot. Cell 2007, 7, 141-153. [CrossRef] [PubMed]

71. Tian, H.; Zhou, L.; Guo, W.; Wang, X. Small GTPase Rac1 and its interaction partner Cla4 regulate polarized growth and pathogenicity in Verticillium dahliae. Fungal Genet. Biol. 2015, 74, 21-31. [CrossRef]

72. Norton, T.S.; Fortwendel, J.R. Control of Ras-mediated signaling in Aspergillus fumigatus. Mycopathol. 2014, 178, 325-330. [CrossRef]

73. Fortwendel, J.R.; Fuller, K.K.; Stephens, T.J.; Bacon, W.C.; Askew, D.S.; Rhodes, J.C. Aspergillus fumigatus RasA Regulates Asexual Development and Cell Wall Integrity. Eukaryot. Cell 2008, 7, 1530-1539. [CrossRef]

74. Tzima, A.; Paplomatas, E.J.; Rauyaree, P.; Kang, S. Roles of the catalytic subunit of cAMP-dependent protein kinase A in virulence and development of the soilborne plant pathogen Verticillium dahliae. Fungal Genet. Biol. 2010, 47, 406-415. [CrossRef]

75. Chen, Y.; Zhai, S.; Sun, Y.; Li, M.; Dong, Y.; Wang, X.; Zhang, H.; Zheng, X.; Wang, P.; Zhang, Z. MoTup1 is required for growth, conidiogenesis and pathogenicity of Magnaporthe oryzae. Mol. Plant Pathol. 2015, 16, 799-810. [CrossRef] [PubMed]

76. Eboigbe, L.; Tzima, A.K.; Paplomatas, E.J.; Typas, M.A. Crosstalk between the cAMP-PKA pathway and the $\beta-1,6$-endoglucanase in Verticillium dahliae. Phytopathol. Mediterr. 2019, 58, 587-595.

77. Sharma, P.; Jha, A.B.; Dubey, R.S.; Pessarakli, M. Reactive oxygen species, oxidative damage, and antioxidative defense mechanism in plants under stressful conditions. J. Bot. 2012. [CrossRef]

78. Broomfield, S.; Chow, B.L.; Xiao, W. MMS2, encoding a ubiquitin-conjugating-enzyme-like protein, is a member of the yeast error-free postreplication repair pathway. Proc. Natl. Acad. Sci. USA 1998, 95, 5678-5683. [CrossRef] [PubMed]

79. Bailly, V.R.; Verly, W.G. AP endonucleases and AP lyases. Nucleic Acids Res. 1989, 17, 3617. [CrossRef] [PubMed]

80. Bailly, V.; Lamb, J.; Sung, P.; Prakash, S.; Prakash, L. Specific complex formation between yeast RAD6 and RAD18 proteins: A potential mechanism for targeting RAD6 ubiquitin-conjugating activity to DNA damage sites. Genes Dev. 1994, 8, 811-820. [CrossRef]

81. Prakash, S.; Sung, P.; Prakash, L. DNA repair genes and proteins of Saccharomyces cerevisiae. Annu. Rev. Genet. 1993, 27, 33-70. [CrossRef]

82. Morrison, A.; Christensen, R.B.; Alley, J.; Beck, A.K.; Bernstine, E.G.; Lemontt, J.F.; Lawrence, C.W. REV3, a Saccharomyces cerevisiae gene whose function is required for induced mutagenesis, is predicted to encode a nonessential DNA polymerase. J. Bacteriol. 1989, 171, 5659-5667. [CrossRef]

83. Jentsch, S.; McGrath, J.P.; Varshavsky, A. The yeast DNA repair gene RAD6 encodes a ubiquitin-conjugating enzyme. Nat. Cell Biol. 1987, 329, 131-134. [CrossRef]

84. Reynolds, P.; Weber, S.; Prakash, L. RAD6 gene of Saccharomyces cerevisiae encodes a protein containing a tract of 13 consecutive aspartates. Proc. Natl. Acad. Sci. USA 1985, 82, 168-172. [CrossRef]

85. O'Rourke, E.J.; Chevalier, C.; Pinto, A.V.; Thiberge, J.M.; Ielpi, L.; Labigne, A.; Radicella, J.P. Pathogen DNA as target for host-generated oxidative stress: Role for repair of bacterial DNA damage in Helicobacter pylori colonization. Proc. Natl. Acad. Sci. USA 2003, 100, 2789-2794. [CrossRef]

86. Da Silva, R.P.; Matsumoto, M.T.; Braz, J.D.; Voltan, A.R.; de Oliveira, H.C.; Soares, C.P.; Giannini, M.J.S.M. Differential gene expression analysis of Paracoccidioides brasiliensis during keratinocyte infection. J. Med. Microbiol. 2011, 60, 269-280. [CrossRef]

87. Wang, L.; Mogg, C.; Walkowiak, S.; Joshi, M.; Subramaniam, R. Characterization of NADPH oxidase genes NoxA and NoxB in Fusarium graminearum. Can. J. Plant Pathol. 2014, 36, 12-21. [CrossRef]

88. Malagnac, F.; Lalucque, H.; Lepère, G.; Silar, P. Two NADPH oxidase isoforms are required for sexual reproduction and ascospore germination in the filamentous fungus Podospora anserina. Fungal Genet. Biol. 2004, 41, 982-997. [CrossRef]

89. Lara-Ortíz, T.; Riveros-Rosas, H.; Aguirre, J. Reactive oxygen species generated by microbial NADPH oxidase NoxA regulate sexual development in Aspergillus nidulans. Mol. Microbiol. 2003, 50, 1241-1255. [CrossRef] [PubMed]

90. Zhao, Y.-L.; Zhou, T.-T.; Guo, H.-S. Hyphopodium-Specific VdNoxB/VdPls1-Dependent ROS-Ca2+ Signaling Is Required for Plant Infection by Verticillium dahliae. PLoS Pathog. 2016, 12, e1005793. [CrossRef] [PubMed]

91. Heller, J.; Tudzynski, P. Reactive Oxygen Species in Phytopathogenic Fungi: Signaling, Development, and Disease. Annu. Rev. Phytopathol. 2011, 49, 369-390. [CrossRef] [PubMed]

92. Bedard, K.; Lardy, B.; Krause, K.-H. NOX family NADPH oxidases: Not just in mammals. Biochimie 2007, 89, 1107-1112. [CrossRef]

93. Bazil, J.N.; Pannala, V.R.; Dash, R.K.; Beard, D.A. Determining the origins of superoxide and hydrogen peroxide in the mammalian NADH:ubiquinone oxidoreductase. Free. Radic. Biol. Med. 2014, 77, 121-129. [CrossRef]

94. Kussmaul, L.; Hirst, J. The mechanism of superoxide production by NADH:ubiquinone oxidoreductase (complex I) from bovine heart mitochondria. Proc. Natl. Acad. Sci. USA 2006, 103, 7607-7612. [CrossRef]

95. Brand, M.D.; Affourtit, C.; Esteves, T.C.; Green, K.; Lambert, A.J.; Miwa, S.; Pakay, J.L.; Parker, N. Mitochondrial superoxide: Production, biological effects, and activation of uncoupling proteins. Free Radic. Biol. Med. 2004, 37, 755-767. [CrossRef] [PubMed]

96. Turrens, J.F. Mitochondrial formation of reactive oxygen species. J. Physiol. 2003, 552, 335-344. [CrossRef] [PubMed]

97. Huang, Q.; Zhou, H.J.; Zhang, H.; Huang, Y.; Hinojosa-Kirschenbaum, F.; Fan, P.; Yao, L.; Belardinelli, L.; Tellides, G.; Giordano, F.J.; et al. Thioredoxin-2 inhibits mitochondrial ROS generation and ASK1 activity to maintain cardiac function. Circulation 2015, 131, 1082. [CrossRef] [PubMed]

98. Hong, S.M.; Lim, H.W.; Kim, I.H.; Kim, K.; Park, E.H.; Lim, C.J. Stress-dependent regulation of the gene encoding thioredoxin reductase from the fission yeast. FEMS Microbiol. Lett. 2006, 234, 379-385. [CrossRef] 
99. Missall, T.A.; Lodge, J.K. Thioredoxin Reductase Is Essential for Viability in the Fungal Pathogen Cryptococcus neoformans. Eukaryot. Cell 2005, 4, 487-489. [CrossRef] [PubMed]

100. Salmon, T.B.; Evert, B.A.; Song, B.; Doetsch, P.W. Biological consequences of oxidative stress-induced DNA damage in Saccharomyces cerevisiae. Nucleic Acids Res. 2004, 32, 3712-3723. [CrossRef]

101. Uziel, O.; Borovok, I.; Schreiber, R.; Cohen, G.; Aharonowitz, Y. Transcriptional Regulation of the Staphylococcus aureus Thioredoxin and Thioredoxin Reductase Genes in Response to Oxygen and Disulfide Stress. J. Bacteriol. 2004, 186, 326-334. [CrossRef]

102. Enjalbert, B.; Nantel, A.; Whiteway, M. Stress-induced Gene Expression in Candida albicans: Absence of a General Stress Response. Mol. Biol. Cell 2003, 14, 1460-1467. [CrossRef] [PubMed]

103. Fradin, C.; Kretschmar, M.; Nichterlein, T.; Gaillardin, C.; D’Enfert, C.; Hube, B. Stage-specific gene expression of Candida albicans in human blood. Mol. Microbiol. 2003, 47, 1523-1543. [CrossRef]

104. Godon, C.; Lagniel, G.; Lee, J.; Buhler, J.-M.; Kieffer, S.; Perrot, M.; Boucherie, H.; Toledano, M.B.; Labarre, J. The $\mathrm{H}_{2} \mathrm{O}_{2}$ Stimulon in Saccharomyces cerevisiae. J. Biol. Chem. 1998, 273, 22480-22489. [CrossRef] [PubMed]

105. Yamazawa, R.; Nakajima, Y.; Mushiake, K.; Yoshimoto, T.; Ito, K. Crystal structure of serine dehydrogenase from Escherichia coli: Important role of the C-terminal region for closed-complex formation. J. Biochem. 2011, 149, 701-712. [CrossRef] [PubMed]

106. Xiong, D.; Wang, Y.; Tian, L.; Tian, C. MADS-Box Transcription Factor VdMcm1 Regulates Conidiation, Microsclerotia Formation, Pathogenicity, and Secondary Metabolism of Verticillium dahliae. Front. Microbiol. 2016, 7, 1192. [CrossRef]

107. Wang, H.; Chen, B.; Tian, J.; Kong, Z. Verticillium dahliae VdBre1 is required for cotton infection by modulating lipid metabolism and secondary metabolites. Environ. Microbiol. 2020. [CrossRef]

108. Tang, C.; Li, T.; Klosterman, S.J.; Tian, C.; Wang, Y. The bZIP transcription factor VdAtf1 regulates virulence by mediating nitrogen metabolism in Verticillium dahliae. New Phytol. 2020, 226, 1461-1479. [CrossRef]

109. Korte-Berwanger, M.; Sakinc, T.; Kline, K.; Nielsen, H.V.; Hultgren, S.; Gatermann, S.G. Significance of the D-serine-deaminase and D-serine metabolism of Staphylococcus saprophyticus for virulence. Infect. Immun. 2013, 81, 4525-4533. [CrossRef]

110. Venugopal, A.; Bryk, R.; Shi, S.; Rhee, K.; Rath, P.; Schnappinger, D.; Ehrt, S.; Nathan, C. Virulence of Mycobacterium tuberculosis Depends on Lipoamide Dehydrogenase, a Member of Three Multienzyme Complexes. Cell Host Microbe 2011, 9, 21-31. [CrossRef] [PubMed]

111. Kong, L.; Cai, Y.; Huang, W.; Cheng, C.H.; Tan, R. Inhibition of xanthine oxidase by some Chinese medicinal plants used to treat gout. J. Ethnopharmacol. 2000, 73, 199-207. [CrossRef]

112. Nagao, A.; Seki, M.; Kobayashi, H. Inhibition of Xanthine Oxidase by Flavonoids. Biosci. Biotechnol. Biochem. 1999, 63, 1787-1790. [CrossRef]

113. Gonzalez, A.G.; Bazzocchi, I.L.; Moujir, L.; Ravelo, Á.G.; Correa, M.D.; Gupta, M.P. Xanthine oxidase inhibitory activity of some Panamanian plants from Celastraceae and Lamiaceae. J. Ethnopharmacol. 1995, 46, 25-29. [CrossRef]

114. Hayashi, T.; Sawa, K.; Kawasaki, M.; Arisawa, M.; Shimizu, M.; Morita, N. Inhibition of cow's milk xanthine oxidase by flavonoids. J. Nat. Prod. 1988, 51, 345-348. [CrossRef]

115. Kang, S.; Metzenberg, R.L. Molecular analysis of nuc-1+, a gene controlling phosphorus acquisition in Neurospora crassa. Mol. Cell. Biol. 1990, 10, 5839-5848. [CrossRef] [PubMed]

116. Kang, S.; Metzenberg, R.L. Insertional mutagenesis in Neurospora crassa: Cloning and molecular analysis of the preg+ gene controlling the activity of the transcriptional activator NUC-1. Genetics 1993, 133, 193-202. [CrossRef]

117. Deng, S.; Wang, C.-Y.; Zhang, X.; Wang, Q.; Lin, L. VdNUC-2, the Key Regulator of Phosphate Responsive Signaling Pathway, Is Required for Verticillium dahliae Infection. PLoS ONE 2015, 10, e0145190. [CrossRef]

118. Kretschmer, M.; Reiner, E.; Hu, G.; Tam, N.; Oliveira, D.L.; Caza, M.; Yeon, J.H.; Kim, J.; Kastrup, C.J.; Jung, W.H.; et al. Defects in Phosphate Acquisition and Storage Influence Virulence of Cryptococcus neoformans. Infect. Immun. 2014, 82, 2697-2712. [CrossRef] [PubMed]

119. Boyce, K.J.; Kretschmer, M.; Kronstad, J.W. The vtc4 Gene Influences Polyphosphate Storage, Morphogenesis, and Virulence in the Maize Pathogen Ustilago maydis. Eukaryot. Cell 2006, 5, 1399-1409. [CrossRef]

120. Jung, W.-H.; Son, Y.-E.; Oh, S.-H.; Fu, C.; Kim, H.S.; Kwak, J.-H.; Cardenas, M.E.; Heitman, J.; Park, H.-S. Had1 Is Required for Cell Wall Integrity and Fungal Virulence inCryptococcus neoformans. G3 Genes I Genomes I Genet. 2018, 8, 643-652. [CrossRef] [PubMed]

121. Lattanzio, V.; Lattanzio, V.M.; Cardinali, A. Role of phenolics in the resistance mechanisms of plants against fungal pathogens and insects. Phytochem. Adv. Res. 2006, 661, 23-67.

122. Wittstock, U.; Gershenzon, J. Constitutive plant toxins and their role in defense against herbivores and pathogens. Curr. Opin. Plant Biol. 2002, 5, 300-307. [CrossRef]

123. Ryan, C.A. Protease inhibitors in plants: Genes for improving defenses against insects and pathogens. Annu. Rev. Phytopathol. 1990, 28, 425-449. [CrossRef]

124. Wink, M. Plant breeding: Importance of plant secondary metabolites for protection against pathogens and herbivores. Theor. Appl. Genet. 1988, 75, 225-233. [CrossRef]

125. Loschke, D.; Hadwiger, L.; Wagoner, W. Comparison of mRNA populations coding for phenylalanine ammonia lyase and other peptides from pea tissue treated with biotic and abiotic phytoalexin inducers. Physiol. Plant Pathol. 1983, 23, 163-173. [CrossRef]

126. Kim, Y.; Komoda, E.; Miyashita, M.; Miyagawa, H. Continuous Stimulation of the Plant Immune System by the Peptide Elicitor PIP-1 Is Required for Phytoalexin Biosynthesis in Tobacco Cells. J. Agric. Food Chem. 2014, 62, 5781-5788. [CrossRef] 
127. Alkher, H.; El Hadrami, A.; Rashid, K.Y.; Adam, L.R.; Daayf, F. Cross-pathogenicity of Verticillium dahliae between potato and sunflower. Eur. J. Plant Pathol. 2009, 124, 505-519. [CrossRef]

128. Uppal, A.K.; El Hadrami, A.; Adam, L.R.; Daayf, F.; Tenuta, M. Pathogenic variability of Verticillium dahliae isolates from potato fields in Manitoba and screening of bacteria for their biocontrol. Can. J. Plant Pathol. 2007, 29, 141-152. [CrossRef]

129. Livak, K.J.; Schmittgen, T.D. Analysis of relative gene expression data using real-time quantitative PCR and the $2^{-\Delta \Delta C T}$ method. Methods 2001, 25, 402-408. [CrossRef]

130. Lund, R.E. Tables for an approximate test for outliers in linear models. Technometrics 1975, 17, 473-476. [CrossRef]

131. Yao, Z.; Islam, R.; Badawi, M.A.; El-Bebany, A.F.; Daayf, F. Overexpression of StRbohA in Arabidopsis thaliana enhances defence responses against Verticillium dahliae. Physiol. Mol. Plant Pathol. 2015, 90, 105-114. [CrossRef] 